\title{
ATMOSPHERIC ACIDITY MEASUREMENTS ON ALLEGHENY MOUNTAIN AND THE ORIGINS OF AMBIENT ACIDITY IN THE NORTHEASTERN UNITED STATES
}

\author{
William R. Pierson*, Wanda W. Brachaczek, Robert A. Gorse, Jr, Steven M. Japar \\ and JOSEPH M. NORBECK \\ Research Staff, Ford Motor Company, P.O. Box 2053, Dearborn, MI 48121, U.S.A.
}

and

\author{
Gerald J. Keeler $\uparrow$ \\ Department of Atmospheric and Oceanic Science, University of Michigan, Ann Arbor, MI 48109, U.S.A.
}

(First received 29 July 1987 and in final form 18 March 1988)

\begin{abstract}
Atmospheric acidity as $\mathrm{HNO}_{3}(\mathrm{~g}), \mathrm{SO}_{2}(\mathrm{~g})$, and aerosol $\mathrm{H}^{+}$was measured on Allegheny Mountain and Laurel Hill in southwest Pennsylvania in August 1983. The aerosol $\mathrm{H}^{+}$appeared to represent the net after $\mathrm{H}_{2} \mathrm{SO}_{4}$ reaction with $\mathrm{NH}_{3}(\mathrm{~g})$. The resulting $\mathrm{H}^{+} / \mathrm{SO}_{4}^{2-}$ ratio depended on $\mathrm{SO}_{4}^{2-}$ concentration, approaching that of $\mathrm{H}_{2} \mathrm{SO}_{4}$ at the highest $\mathrm{SO}_{4}^{2-}$ concentrations. The atmosphere was acidic; the average

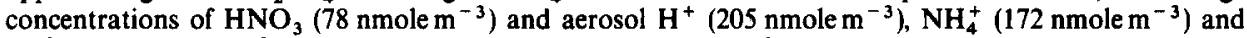
$\mathrm{SO}_{4}^{2-}\left(201 \mathrm{nmole} \mathrm{m}^{-3}\right)$, and the dearth of $\mathrm{NH}_{3}\left(<15 \mathrm{nmolem}^{-3}\right)$, show that the proton acidity $\left(\mathrm{HNO}_{3}\right.$, $\mathrm{H}_{2} \mathrm{SO}_{4}$ ) of the air exceeded the acid-neutralizing capacity of the air by a factor of $>2$, with one 10-h period averaging 263 and $844 \mathrm{nmole} \mathrm{m}^{-3}$ for $\mathrm{HNO}_{3}$ and aerosol $\mathrm{H}^{+}$, respectively. $\mathrm{SO}_{2}$ added another $900 \mathrm{nmole}$ $\mathrm{m}^{-3}$ (average) of potential $\mathrm{H}^{+}$acidity. $\mathrm{HNO}_{3}$ and aerosol $\mathrm{H}^{+}$episodes were concurrent, on 7-8 day cycles, unrelated to $\mathrm{SO}_{2}$ which existed more in short-lived bursts of apparently more local origin. $\mathrm{NO}_{x}$ was sporadic like $\mathrm{SO}_{2}$. Laurel and Allegheny, separated by $35.5 \mathrm{~km}$, were essentially identical in aerosol $\mathrm{SO}_{4}^{2-}$, and in aerosol $\mathrm{H}^{+}$, less so in $\mathrm{HNO}_{3}$ and especially less so in $\mathrm{SO}_{2}$; apparently, chemistry involving $\mathrm{HNO}_{3}$ and aerosol $\mathrm{H}^{+}$or $\mathrm{SO}_{4}^{2-}$ was slow compared to inter-site transport times $(1-2 \mathrm{~h})$. From growth of $b_{\text {scat }}$ and decline of $\mathrm{SO}_{2}$ during one instance of inter-site transport, daytime rate coefficients for $\mathrm{SO}_{2}$ oxidation and $\mathrm{SO}_{2}$ dry deposition were inferred to have been, respectively, $\sim 0.05$ and $\leqslant 0.1 \mathrm{~h}^{-1}$.

$\mathrm{HNO}_{3}$ declined at night. Aerosol $\mathrm{H}^{+}$and $\mathrm{SO}_{4}^{2-}$ showed no significant diurnal variation, and $\mathrm{O}_{3}$ showed very little; these observations, together with high PAN/NO ${ }_{x}$ ratios, indicate that regional transport rather than local chemistry is governing. The $\mathrm{O}_{3}$ concentration (average $56 \mathrm{ppb}$ or $2178 \mathrm{nmole} \mathrm{m}^{-3}$ ) connotes an oxidizing atmosphere conducive to acid formation.

Highest atmospheric acidity was associated with (1) slow westerly winds traversing westward $\mathrm{SO}_{2}$ source areas, (2) local stagnation, or (3) regional transport around to the back side of a high pressure system. Low acidity was associated with fast-moving air masses and with winds from the northerly directions; upwind precipitation also played a moderating role in air parcel acidity. Much of the $\mathrm{SO}_{2}$ and $\mathrm{NO}_{x}$, and ultimately of the $\mathrm{HNO}_{3}$ and aerosol $\mathrm{H}^{+}$, appeared to originate from coal-fired power plants. An automotive contribution to the $\mathrm{NO}_{x}$ and $\mathrm{HNO}_{3}$ could not be discerned.

Size distributions of aerosol $\mathrm{H}^{+}$and $\mathrm{SO}_{4}^{2-}$ were alike, with $\mathrm{MMED} \sim 0.7 \mu \mathrm{m}$, in the optimum range for efficient light scattering and inefficient wet/dry removal. Thus, light scattering and visual range degradation were attributable to the acidic $\mathrm{SO}_{4}^{2-}$ aerosol, linking the issues of acid deposition and visual air quality in the Northeast. With inefficient removal of aerosol $\mathrm{H}^{+}$, and inefficient night-time removal of $\mathrm{HNO}_{3}$, strong acids may be capable of long-distance transport in the lower troposphere.

We obtained an accounting of aerosol mass in terms of composition, including aerosol $\mathrm{H}_{2} \mathrm{O}$ which was shown to account for much of the light scattering.
\end{abstract}

Key word index: Acid rain, acid deposition, atmospheric acidity, atmospheric aerosols, nitric acid, regional transport, sulfate.

\section{INTRODUCTION}

Ten years ago on Allegheny Mountain in Pennsylvania, we conducted an experiment which revealed a

* Author to whom correspondence should be addressed. Present address: Energy and Environmental Engineering Center, Desert Research Institute, P.O. Box 60220, Reno, NV 89506, U.S.A. † Present address: Harvard School of Public Health, 665 Huntington Avenue, Boston, MA 02115, U.S.A. strong and persistent acidity in aerosol in that part of the country (Pierson et al., 1980). The aerosol was found to consist essentially of $\mathrm{H}_{2} \mathrm{SO}_{4}$ in various degrees of neutralization by $\mathrm{NH}_{3}(\mathrm{~g})$, together with its water of hydration, the degree of neutralization being greatest at the lowest $\mathrm{SO}_{4}^{2-}$ concentrations. $\mathrm{NH}_{3}(\mathrm{~g})$ levels were very low (average $<1.1 \mathrm{ppb}$ ). The most acidic aerosol and the highest $\mathrm{SO}_{4}^{2-}$ levels were associated with air masses arriving from westward, especially when there had been stagnation over $\mathrm{SO}_{2}$ source 
regions along the Ohio River (Samson, 1980). Visibility degradation at Allegheny was also very much governed by the light scattering of this fine $(\sim 0.8 \mu \mathrm{m}$ mass median diameter) acidic sulfate aerosol. Coincidentally, acidic aerosol $\mathrm{SO}_{4}^{2-}$ episodes and associated haze were being detected at sites in North Carolina, New Jcrsey and New York (Lioy et al., 1980; Stevens et al., 1978; Tanner et al., 1981)-and, indeed, in a network (SURE) encompassing the whole Northeast (Mueller et al., 1980)-thus demonstrating that the phenomena observed on Allegheny Mountain in 1977 were regional in nature. It is now established (Charlson et al., 1978; Cunningham and Johnson, 1976; Dzubay et al., 1979; Ferek et al., 1983; Ferman et al., 1981; Lioy and Lippmann, 1986; Lioy et al., 1980; Morandi et al., 1983; Pierson, 1981; Stevens et al., 1978, 1980, 1984; Tanner et al., 1977, 1981, 1984; Weiss et al., 1982) that the aerosol in the eastern U.S. is commonly acidic and that the acidity identifies with $\mathrm{H}_{2} \mathrm{SO}_{4}$ and $\mathrm{NH}_{4} \mathrm{HSO}_{4}$.

$\mathrm{SO}_{2}(\mathrm{~g})$, largely uncorrelated with aerosol $\mathrm{SO}_{4}^{2-}$, was about twice as abundant as the $\mathrm{SO}_{4}^{2-}$, on a mole average basis, in the experiment ten years ago. However, knowledge of the total amount of acid in the air was lacking in that there were no measurements of $\mathrm{HNO}_{3}(\mathrm{~g})$. Moreover, interpretation of the aerosol $\mathrm{H}^{+}$ and $\mathrm{SO}_{4}^{2-}$ data was limited by absence of $\mathrm{O}_{3}$ data.

In 1983 we conducted a larger experiment on top of Allegheny Mountain and concurrently $35.5 \mathrm{~km}$ away on Laurel Hill. This time $\mathrm{HNO}_{3}(\mathrm{~g})$ and $\mathrm{O}_{3}$ were included. Acidity deposited in rain, dew, and to dry surrogate surfaces in this study are discussed elsewhere (Japar et al., 1985; Pierson et al., 1986, 1987), including estimates of the acid deposited during the study and of the relative contributions to it of wet and dry deposition of $\mathrm{SO}_{2}, \mathrm{HNO}_{3}$ and aerosol $\mathrm{H}^{+}$(Pierson et al., 1987).

The present paper deals with these three atmospheric gas and aerosol acidic species- $\mathrm{SO}_{2}, \mathrm{HNO}_{3}$, aerosol $\mathrm{H}^{+}$- as the proximate cause of the acidity deposited in the 1983 experiment. $\mathrm{SO}_{2}$ is included because it is a strong Lewis acid and is responsible for much of the $\mathrm{H}^{+}$and $\mathrm{SO}_{4}^{2-}$ in rain (e.g. Pierson et al., 1987) and because $\mathrm{SO}_{2}$ dry deposition is tantamount to deposition of $\mathrm{H}_{2} \mathrm{SO}_{4}$ by virtue of the ease of $\mathrm{SO}_{2}$ conversion to $\mathrm{H}_{2} \mathrm{SO}_{4}$. Atmospheric $\mathrm{HCl}, \mathrm{HONO}$ and carboxylic acids were not evaluated, but analyses of rain, dew and fog in this study (Pierson et al., 1986, 1987) indicate that their atmospheric concentrations must have been relatively meager, or at least that their contributions to deposited acidity in dew, rain and fog were meager. Weak acids, including dicarboxylic acids, are said (Ferek et al., 1983) to have constituted $26 \pm 12 \%$ of the total acidity in a situation in the Northeast less acidic than the present one, suggesting that their contribution here was likely $<25 \%$. PAN was measured here but played no discernible role in acid deposition (rain, dew, fog; Pierson et al., 1986, 1987) and is therefore excluded from our atmospheric acidity totals. $\mathrm{NO}$ and $\mathrm{NO}_{2}$ were measured also, and played no discernible role in dew acidity (Pierson $e t$ al., 1986); accordingly, and because they are not acid anhydrides, they too are excluded from the acid totals. $\mathrm{NO}_{2}$ could have contributed to local in-stormgenerated $\mathrm{HNO}_{3}$ through reaction with $\mathrm{OH}$ (Chang, 1986). $\mathrm{NO}_{3}$ and especially $\mathrm{N}_{2} \mathrm{O}_{5}$, neither of which were evaluated by measurement, and both of which are excluded from the acid totals, could have contributed to the $\mathrm{HNO}_{3}$ in dew (Chang et al., 1987) and to instorm-generated $\mathrm{HNO}_{3}$ (Chang, 1986). We estimate, however, that most of the $\mathrm{HNO}_{3}$ in the local rain came from scavenging of pre-existing $\mathrm{HNO}_{3}$ rather than from in-stormgeneration of $\mathrm{HNO}_{3}$ (Pierson et al., 1987). Thus the exclusion of $\mathrm{NO}_{2}, \mathrm{NO}_{3}$ and $\mathrm{N}_{2} \mathrm{O}_{5}$ is probably a minor issue (at most $\sim 20 \%$ of the potential acidity; see later). Under the humid night-time conditions prevailing at Allegheny or Laurel, it could be that some of the $\mathrm{N}_{2} \mathrm{O}_{5}$ was counted as $\mathrm{HNO}_{3}$ as discussed below.

\section{EXPERIMENTAL}

The measurements in the present study were conducted in August 1983 (5-28 August) at two abandoned mountaintop radio towers in a rural area in southwestern Pennsylvania (Fig. 1), some $150 \mathrm{~km}$ east of the highest density of $\mathrm{SO}_{2}$ emissions in the U.S. (Barrie et al., 1984; Clark, 1980). One tower, on Allegheny Mountain $\left(39.959^{\circ} \mathrm{N}, 78.8525^{\circ} \mathrm{W}\right.$, elevation $838 \mathrm{~m}$ ), was the site used in the 1977 study (Pierson $e t$ al., 1980). The other, on Laurel Hill $\left(40.099^{\circ} \mathrm{N}, 79.226^{\circ} \mathrm{W}\right.$, elevation $850 \mathrm{~m}$ ), lies $35.5 \mathrm{~km}$ WNW (bearing $296^{\circ}$ True) from the Allegheny tower. There are no significant industrial sources near or in the tableland between the two mountaintops. Both sites are heavily forested. There is no local traffic, though occasionally at Allegheny brief excursions of condensation nuclei count (CNC), NO and (downward excursions) $\mathrm{O}_{3}$ were noted with wind from the direction of the east portal of the Allegheny Mountain Tunnel (Pennsylvania Turnpike), some $420 \mathrm{~m}$ slant distance away (bearing $120^{\circ} \mathrm{T}$ ) and $143 \mathrm{~m}$ lower in elevation.

At Allegheny the atmospheric aerosol and gas measurements were made on the tower $14-17 \mathrm{~m}$ above the ground. The plane of the treetops was $12.3 \mathrm{~m}$ above the ground. Light scattering (by heated-inlet integrating nephelometer, cell temperature $\sim 16^{\circ} \mathrm{C}$ above ambient), light absorption (by an integrating-plate method; see Japar et al., 1986), CNC, and ultraviolet radiation intensity were measured at the same elevation. Visual ranges to natural targets $3.2-35.5 \mathrm{~km}$ away were recorded from time to time and hourly visual range observations were obtained from the NWS (National Weather Service) stations at Johnstown and Altoona/Martinsburg, Pennsylvania (see Fig. 1). Wind speed and direction at the towers were monitored $20.6 \mathrm{~m}$ above the ground. Atmospheric temperature, pressure, relative humidity (r.h.) and dewpoint were continuously recorded.

At Laurel the atmospheric aerosol and gas measurements, as well as the measurements of light scattering and u.v radiation intensity, were made on the (slightly taller) tower $18-21 \mathrm{~m}$ above the ground. Wind speed and direction were monitored $24.5 \mathrm{~m}$ above the ground. Atmospheric temperature, pressure and r.h. were continuously recorded. Mixing height was monitored with an acoustic sounder. Pibals were released on most days, equipped with radiosonde and tracked by theodolite, to obtain vertical profiles of wind speed, wind direction and temperature and pressure. The plane of the treetops at Laurel was $16.5 \mathrm{~m}$ above the ground. 

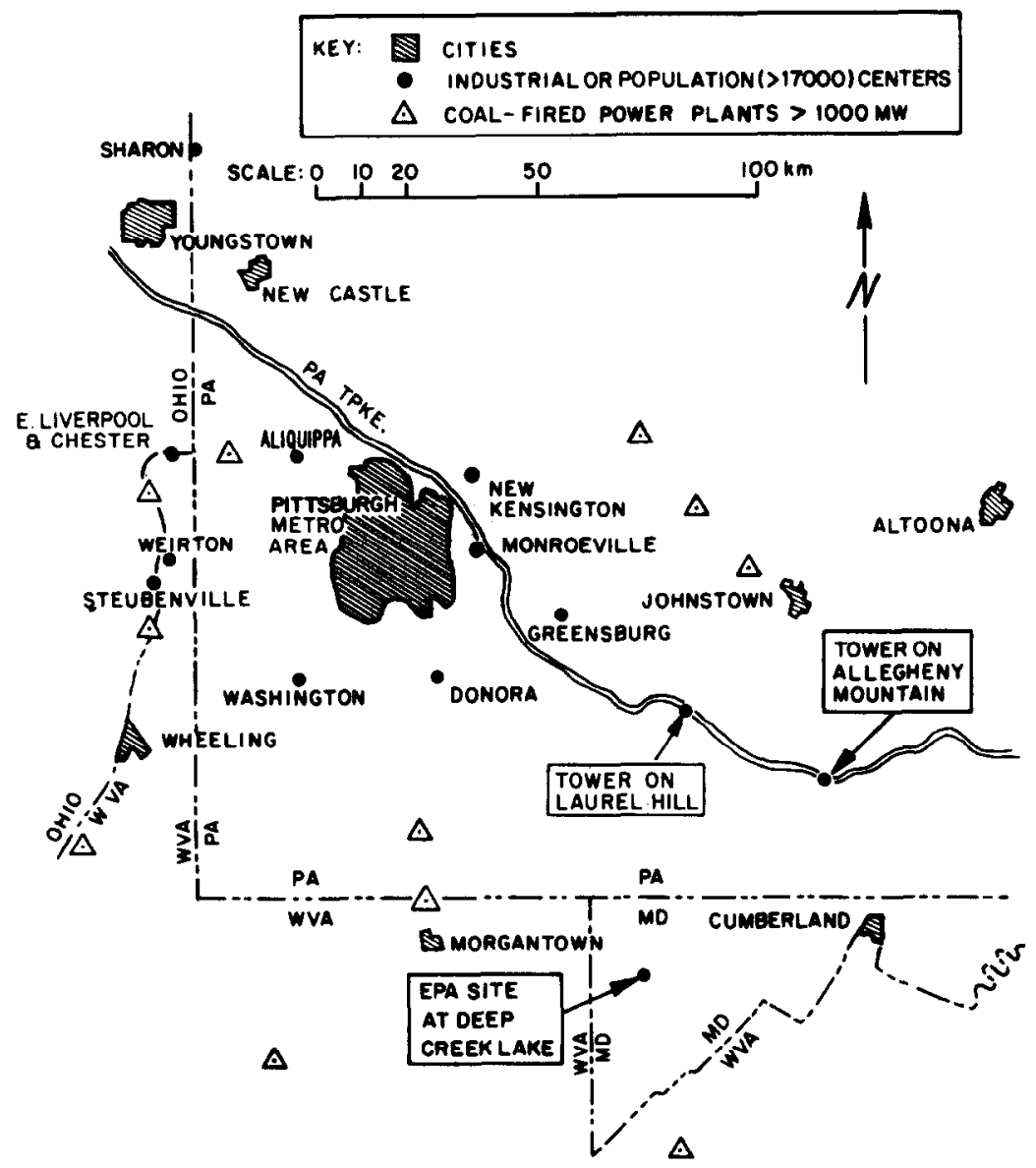

Fig. 1. Map of the sourthwestern Pennsylvania vicinity of the Allegheny Mountain/Laurel Hill experiment.

Mixed-layer 72-h back trajectories for air arriving at the sites at $0200,0800,1400$ and 2000 EDT daily were generated from NWS data by methods described by Hefiter (1980) and by Samson (1980). Exact times of frontal passage were determined from the recorded temperature, pressure, humidity/dewpoint and wind speed and direction. Surface trajectories and 850-mb trajectories were also obtained from the NWS for 0800 and 2000 EDT arrival each day.

The atmospheric gases measured at Allegheny included $\mathrm{NO}_{2}$ (together with PAN) and NO continuously, by a chemiluminescence NO monitor, PAN semi-continuously by a gas chromatograph with an electron-capture detector (Holdren and Spicer, 1984); $\mathrm{O}_{3}$ continuously by u.v. absorption; $\mathrm{SO}_{2}$ by a $\mathrm{H}_{2} \mathrm{O}_{2}$ impinger collection method followed by ion chromatographic analysis as $\mathrm{SO}_{4}^{2-}$ (Pierson et al., 1980); and $\mathrm{SO}_{2}$ continuously by pulsed u.v. fluorescence. $\mathrm{HNO}_{3}(\mathrm{~g})$ and aerosol $\mathrm{NO}_{3}^{-}$were measured by the denuder-difference method (Appel et al., 1981; Shaw et al., 1982; Spicer et al., 1982) using MgO-coated denuder tubes and nylon membrane filters (nominal pore diameter $1 \mu \mathrm{m}$ ), with ion chromatographic $\mathrm{NO}_{3}^{-}$determination on dilute-base extracts of the filters. The inlet of the denuder-difference apparatus was a Teflon cyclone with a 1.5- $\mu \mathrm{m}$ cutoff ("Cyclone II" of Smith et al., 1979) to exclude large-particle $\mathrm{NO}_{3}^{-}$that might otherwise deposit in the denuder and be mistaken for $\mathrm{HNO}_{3}$. Significant amounts of $\mathrm{N}_{2} \mathrm{O}_{3}(\mathrm{~g})$ can be expected at night (Chang $e t$ al., 1987); the possibility that $\mathrm{N}_{2} \mathrm{O}_{5}$ could register to some degree as $\mathrm{HNO}_{3}$ in the denuder-difference apparatus at high humidities (Spicer, 1986), as often occur at night at Allegheny, was not evaluated. $\mathrm{NH}_{3}(\mathrm{~g})$ was determined by oxalic-acidcoated denuder tubes (Ferm, 1979; Hara et al., 1982). Valid $\mathrm{NH}_{3}(\mathrm{~g})$ data were obtained in only a few runs because of problems of water condensation in the denuder tubes.

The Laurel gas measurements included $\mathrm{NO}_{x}$ (meaning NO $+\mathrm{NO}_{2}+\mathrm{PAN}$ ), but not $\mathrm{NO}$ and $\mathrm{NO}_{2}$ separately, by chemiluminescence; $\mathrm{SO}_{2}$ as above; $\mathrm{HNO}_{3}(\mathrm{~g})$ as above; and $\mathrm{NH}_{3}(\mathrm{~g})$ as above and with the same problems.

Aerosol samples at Allegheny and Laurel were collected as follows:

(1) with HiVol samplers equipped with cyclone preseparators to exclude particles larger than $2.5 \mu \mathrm{m}$, using $8^{\prime \prime}$ $\times 10^{\prime \prime}$ quartz-fiber filters prefired in air overnight at $600^{\circ} \mathrm{C}$

(2) on 142-mm diameter Teflon membrane filters, nominal pore diameter $0.2 \mu \mathrm{m}$, using an inlet to exclude particles larger than $\sim 10 \mu \mathrm{m}$;

(3) in dichotomous samplers on pairs of preweighed (at $20^{\circ} \mathrm{C}$ and $50 \%$ r.h.) $37-\mathrm{mm}$ Teflon membrane filters, nominal pore diameters $1.0 \mu \mathrm{m}$, one filter for fine $(<2.5 \mu \mathrm{m})$ particles and the other for coarse ( $>2.5 \mu \mathrm{m})$, each sampler being equipped with an inlet to exclude particles $>15 \mu \mathrm{m}$ (first 16 runs) or $>10 \mu \mathrm{m}$ (subsequent runs);

(4) in 8-stage Andersen cascade impactors at Allegheny only, with cellulose filters (Whatman 41) for impactor plates and with quartz-fiber backup filters;

(5) on the nylon membrane filters of the denuder-difference apparatus. 
The HiVol filters, 142-mm filters, and impaction substrates were sealed in airtight bags or other containment immediately after collection to keep out $\mathbf{N H}_{3}$. All samples were stored in the dark at room temperature. Even so, it is recognized that reactions with ambient $\mathrm{NH}_{3}(\mathrm{~g})$ during sampling will cause aerosol $\mathrm{H}^{+}$to be underestimated and aerosol $\mathrm{NH}_{4}^{+}$commensurately overestimated; this effect was suppressed in other work (Stevens et al., 1978) by means of a $\mathrm{NH}_{3}$ denuder upstream of the filter.

The aerosol filter samples were analyzed as follows.

(1) The $\mathrm{HiVol}$ filters were analyzed for $\mathrm{H}^{+}, \mathrm{NH}_{4}^{+}$, and $\mathrm{SO}_{4}^{2-}$ within a few weeks after sampling, by $\mathrm{pH}$ measurement and ion chromatography on aqueous extracts. They were also analyzed for total S by combustion using a LECO analyzer, for elemental and organic carbon (EC and OC) by a thermal/optical technique (Huntzicker et al., 1982), and for trace elements by inductively coupled argon plasma atomic emission spectroscopy (ICP/AES). For the trace elements, samples were prepared by strong acid digestion in Parr bombs.

(2) The 142-mm Teflon membrane filters were analyzed for $\mathrm{H}^{+}, \mathrm{NH}_{4}^{+}$and $\mathrm{SO}_{4}^{2-}$ as above.

(3) The dichotomous sampler filters were analyzed for fine and coarse mass gravimetrically (at $20^{\circ} \mathrm{C}$ and $50 \%$ r.h.), and for $S$ and 47 other elements by $x$-ray fluorescence and neutron activation analysis (by NEA, Inc.).

(4) The cascade impactor size distributions of $\mathrm{H}^{+}, \mathrm{NH}_{4}^{+}$and $\mathrm{SO}_{4}^{2-}$ were determined by $\mathrm{pH}$ measurement and ion chromatography on aqueous extracts. The size distributions of 23 trace elements were determined on aciddigested samples by ICP/AES and by atomic absorption.

(5) The nylon filters were analyzed for $\mathrm{NO}_{3}^{-}$and $\mathrm{SO}_{4}^{2-}$ by extraction and ion chromatography as stated above.

There were $\mathbf{4 4}$ air sampling runs at Allegheny ranging in duration from 23 to $1610 \mathrm{~min}$ and 39 runs at Laurel ranging from 200 to $1409 \mathrm{~min}$. The sampling schedule was the same for filters, denuders and impingers at a given site and, with a few exceptions, between sites. The samplers generally were started each morning when the acoustic sounder and other meteorological data indicated the development of a mixed layer and were stopped in the early evening when the layer was seen to be collapsing. At night the sampling times were generally dictated by the onset and end of dew formation. On a few occasions, sampling was timed to coincide with rain.

The sampling schedule for the cascade impactors was dictated by the analytical detection limits and by the attempt to obtain size distributions during rain only; five impactor samples ranging in duration between 146 and $9497 \mathrm{~min}$ spanned the experiment.

\section{RESULTS}

The most important results of the present study are as follows.

(1) The air was decidedly acidic, with an overwhelming predominance of $\mathrm{HNO}_{3}(\mathrm{~g})$ and aerosol $\mathrm{H}^{+}$over any base including $\mathrm{NH}_{3}(\mathrm{~g})$ or aerosol trace minerals. Aerosol $\mathrm{H}^{+}$contributed not quite 3 times as much acidity as did $\mathrm{HNO}_{3}(\mathrm{~g})$, with averages 205 and $78 \mathrm{nmole} \mathrm{m}^{-3}$, respectively, and one overnight period averaging 844 and $263 \mathrm{nmole} \mathrm{m}^{-3}$, respectively. The potential for acidification by $\mathrm{SO}_{2}$ was even greater since its average concentration was $\sim 450$ nmole $m^{3}$ or, in potential $\mathrm{H}^{+}$, $\sim 900$ neq $\mathrm{m}^{-3}$ (3600 neq $\mathrm{m}^{-3}$ maximum).
(2) The aerosol was mostly aqueous $\mathrm{H}_{2} \mathrm{SO}_{4}$ partly neutralized to $\mathrm{NH}_{4}^{+}$salts, with mean particle diameter $\sim 0.8 \mu \mathrm{m}$ and with $\mathrm{SO}_{4}^{2-}$ constituting $\sim 1 / 3$ of the aerosol mass on the average $(\sim 1 / 2$ at maximum). The $\mathrm{SO}_{4}^{2-}$ concentration ranged between 36 and $1156 \mathrm{neq} \mathrm{m}^{-3}\left(2-55 \mu \mathrm{g} \mathrm{m}^{-3}\right)$. The aerosol $\mathrm{SO}_{4}^{2-}$ was essentially stoichiometric with the sum of $\mathrm{NH}_{4}^{+}$and $\mathrm{H}^{+}$. The aerosol $\mathrm{H}^{+} / \mathrm{SO}_{4}^{2-}$ ratio was a function of $\mathrm{SO}_{4}^{2-}$ concentration, and ranged from $0.4 \mathrm{~mole} / \mathrm{mole}$ at the lowest $\mathrm{SO}_{4}^{2-}$ concentrations to 1.46 at the highest, with a mean of 1.0 .

(3) Episodes of high $\mathrm{SO}_{4}^{2-}$ occurred every 7 or 8 days and lasted several days.

(4) Consistent with the high aerosol $\mathrm{H}^{+}$levels, $\mathrm{NH}_{3}(\mathrm{~g})$ was extremely low $\left(<15 \mathrm{nmole}^{-3}\right.$ or $<0.4 \mathrm{ppb}$ ).

(5) Also consistent with the high aerosol $\mathrm{H}^{+}$levels, $\sim 90 \%$ of the inorganic nitrate $\left(\mathrm{HNO}_{3}+\right.$ aerosol $\mathrm{NO}_{3}^{-}$) existed as $\mathrm{HNO}_{3}(\mathrm{~g})$.

(6) The $\mathrm{HNO}_{3}(\mathrm{~g})$ concentrations followed 7- or 8day cycles similar to, and concurrent with, the $\mathrm{SO}_{4}^{2-}$ cycles.

(7) The night-time average $\mathrm{HNO}_{3}$ (g) concentration was lower than the daytime average. The $\mathrm{O}_{3}$ diurnal variation was small.

(8) High concentrations of $\mathrm{HNO}_{3}(\mathrm{~g}), \mathrm{SO}_{2}$ and aerosol $\mathrm{H}^{+}$and $\mathrm{SO}_{4}^{2-}$ all tended to be associated with stagnation and air masses from westward, though the $\mathrm{HNO}_{3}$ and $\mathrm{SO}_{2}$ were not particularly well correlated with each other or with the aerosol $\mathrm{H}^{+}$and $\mathrm{SO}_{4}^{2-}$.

(9) Low concentrations of $\mathrm{HNO}_{3}(\mathrm{~g}), \mathrm{SO}_{2}, \mathrm{O}_{3}$ and aerosol $\mathrm{H}^{+}$and $\mathrm{SO}_{4}^{2-}$ were associated with fastmoving air masses and air masses from northerly directions. Upwind precipitation also made for lower concentrations.

(10) The correlations of the aerosol species $\mathrm{H}^{+}, \mathrm{NH}_{4}^{+}$, $\mathrm{SO}_{4}^{2-}$ at Allegheny with their counterparts at Laurel were extremely high $(r \sim 0.96)$, demonstrating that the distance scale for the chemistry involving these species was $\gg 35 \mathrm{~km}$. The intersite couplings in the case of $\mathrm{HNO}_{3}$ and $\mathrm{SO}_{2}$ were weaker $(r \sim 0.8)$.

(11) Light scattering and visibility degradation were attributable to the acidic $\mathrm{SO}_{4}^{2-}$ aerosol.

The results will be discussed in more detail below. Many of them confirm results from the 1977 experiment.

\section{Weather during the experiment}

Average values of some of the meteorological variables are listed in Table 1. The mixed-layer winds (averaged from the surface to the top of the mixing layer; Heffter, 1980; Samson, 1980) were mostly westerly but there were many exceptions, including a 4-day period beginning on 12 August when winds were steadily out of the NNE. This period was character- 
Table 1. Averages of some meteorological variables during the August 1983 Allegheny Mountain/Laurel Hill experiment

\begin{tabular}{lcc}
\hline & Allegheny & Laurel \\
\hline Wind speed $\left(\mathrm{m} \mathrm{s}^{-1}\right)$, mixed layer & 4.5 & 4.4 \\
Wind speed $\left(\mathrm{m} \mathrm{s}^{-1}\right)$, at tower & 3.9 & 3.1 \\
Wind direction origin at tower $\left({ }^{\circ}\right.$ True $)$ & 270 & 267 \\
Temperature $\left({ }^{\circ} \mathrm{C}\right)$ & 20 & 21 \\
Relative humidity $(\%)$ & 78 & 72 \\
Dewpoint $\left({ }^{\circ} \mathrm{C}\right)$ & 14.5 & - \\
Barometer $(\mathrm{mm} \mathrm{Hg})$ & 699 & 700 \\
Daily maximum mixing ht $(\mathrm{m})$ & - & $1500^{\mathrm{a}}$ \\
Daytime u.v. intensity $\left(\mathrm{W} \mathrm{m}^{-2}\right)$ & 16.9 & 16.9 \\
Visual range $(\mathrm{km})$ & $21^{\mathrm{b}}$ & - \\
$b_{\text {scas }}\left(\mathrm{m}^{-1}\right)$ & $\left(1.9 \times 10^{-4}\right)^{\mathrm{c}}$ & $\left(1.9 \times 10^{-4}\right)^{\mathrm{c}}$ \\
$b_{\text {abs }}\left(\mathrm{m}^{-1}\right)$ & $1.9 \times 10^{-5}$ & - \\
Condensation nuclei count $\left(\mathrm{cm}^{-3}\right)$ & 5776 & - \\
Daily average rainfall $(\mathrm{mm})$ & 2.2 & 0.6 \\
\hline
\end{tabular}

"Median value of the daily maxima. obtained from acoustic sounder and radiosonde data and estimates of heights of cloud tops.

Daytime only and without fog.

' With heated nephelometer inlet. Cell temperature is $\sim 15^{\circ} \mathrm{C}$ above ambient.

ized by low temperature, about-average humidity, no rain, maximum visual range ( $>35 \mathrm{~km})$, minimum $b_{\text {scat }}$ (Fig. 2, runs 12-19) and minimum or near-minimum values of most species including $\mathrm{HNO}_{3}, \mathrm{SO}_{2}$ and aerosol mass (coarse and fine), $\mathrm{H}^{+}, \mathrm{NH}_{4}^{+}$and $\mathrm{SO}_{4}^{2-}$ (Fig. 2).

With one or two exceptions, a surface inversion developed every night. The night-time inversion began to break at about 0745 , and by noon a well-mixed layer had developed, of height 550 to $>2500 \mathrm{~m}$, which collapsed quickly (within 1-h or so) around 1915. As is typical of this locality and elevation, the average overnight r.h. was high ( $85 \%$ at Allegheny, $78 \%$ at Laurel), and there was always heavy dew on a clear night (Pierson et al., 1986). The sites were in cloud on at least seven occasions at Allegheny and four at Laurel.

The mixing-height measurements were difficult, and the radiosonde and acoustic sounder data did not always agree. On all but one day (19 August), the maximum mixing height exceeded the range setting of the acoustic sounder chart $(500 \mathrm{~m}$ in the first 10 days, $1000 \mathrm{~m}$ afterwards); when the range was exceeded, mixing heights were obtained by visual estimate of the height of the cloud tops (believed to be gaugeable to within $\pm 300 \mathrm{~m}$ ) and/or from the radiosonde data.

\section{Average concentrations}

Time-average concentrations of the atmospheric species pertinent to the present discussion are listed in Table 2. The numbers document some of the results already stated. The ambient acidity is evident in the $\mathrm{HNO}_{3}(\mathrm{~g})$ and in the larger amounts of aerosol $\mathrm{H}^{+}$, the lack of $\mathrm{NH}_{3}(\mathrm{~g})$ or potentially alkaline aerosol constituents $(\mathrm{Mg}, \mathrm{Ca}$, etc.), and the further acidification potential represented by $\mathrm{SO}_{2}$. The near stoichiometry of the aerosol $\mathrm{H}^{+}$and $\mathrm{NH}_{4}^{+}$with the $\mathrm{SO}_{4}^{2-}$, which in turn represents much of the aerosol mass, and the lack of other ions in significant amounts, suggests an aqueous $\left(\mathrm{NH}_{4}\right)_{x} \mathrm{H}_{(2-x)} \mathrm{SO}_{4}$ aerosol with $0<x<2$ and $\bar{x}$ approximately 1.0. The dearth of $\mathrm{NH}_{3}(\mathrm{~g})$ is consistent with the pronounced aerosol acidity, as is also the lack of aerosol $\mathrm{NO}_{3}^{-}-$most of the inorganic $\mathrm{NO}_{3}^{-}$is present as $\mathrm{HNO}_{3}(\mathrm{~g})-$ or of aerosol Cl. Comparison of the $\left(\mathrm{NH}_{3}+\right.$ aerosol $\left.\mathrm{NH}_{4}^{+}\right)$with $\left(\mathrm{HNO}_{3}\right.$ + aerosol $\mathrm{NO}_{3}^{-}+$aerosol $\mathrm{SO}_{4}^{2-}$ ) suggests that generally there was initially only enough $\mathrm{NH}_{3}(\mathrm{~g})$ to neutralize about $35 \%$ of the $\mathrm{HNO}_{3}$ and $\mathrm{H}_{2} \mathrm{SO}_{4}$ produced or emitted.

The average compositions at the two sites are similar. Concentrations tended to be marginally higher at Laurel than at Allegheny and the Laurel aerosol was less neutralized than the Allegheny aerosol $\left(\mathrm{H}^{+} / \mathrm{NH}_{4}^{+} / \mathrm{SO}_{4}^{2-}=1.05 / 0.83 / 1\right.$ at Laurel vs 1.01/0.88/1 at Allegheny). Since Allegheny was usually downwind of Laurel, these differences are qualitatively plausible.

Figure 3 shows that high $\mathrm{H}^{+} / \mathrm{SO}_{4}^{2-}$ ratios in the aerosol were favored at high $\mathrm{SO}_{4}^{2-}$ concentrations, and that high $\mathrm{NH}_{4}^{+} / \mathrm{SO}_{4}^{2-}$ ratios were favored at the lowest $\mathrm{SO}_{4}^{2-}$ concentrations though a fully neutralized $\left(\mathrm{NH}_{4}\right)_{2} \mathrm{SO}_{4}$ aerosol was never observed. Finally, the sum of $\mathrm{H}^{+} / \mathrm{SO}_{4}^{2-}$ and $\mathrm{NH}_{4}^{+} / \mathrm{SO}_{4}^{2-}$ mole ratios, 1.88 or essentially 2.0 , was independent of $\mathrm{SO}_{4}^{2-}$ concentration. The same behavior was seen in the 1977 Allegheny experiment, and suggests that the degree of neutralization of the $\mathrm{H}_{2} \mathrm{SO}_{4}$ aerosol depends on how much there was to neutralize.

Figure 2 shows that in the most pronounced $\mathrm{SO}_{4}^{2-}$ episode, the one that ran from around 16 August to 20 August, the first half of the episode had a more acidic aerosol than did the second part. That is, the high $\mathrm{H}^{+}$ (or $\mathrm{H}^{+} / \mathrm{SO}_{4}^{2-}$ ratio) tended to be in the build-up phase of the episode and the high $\mathrm{NH}_{4}^{+}$tended to be in the 


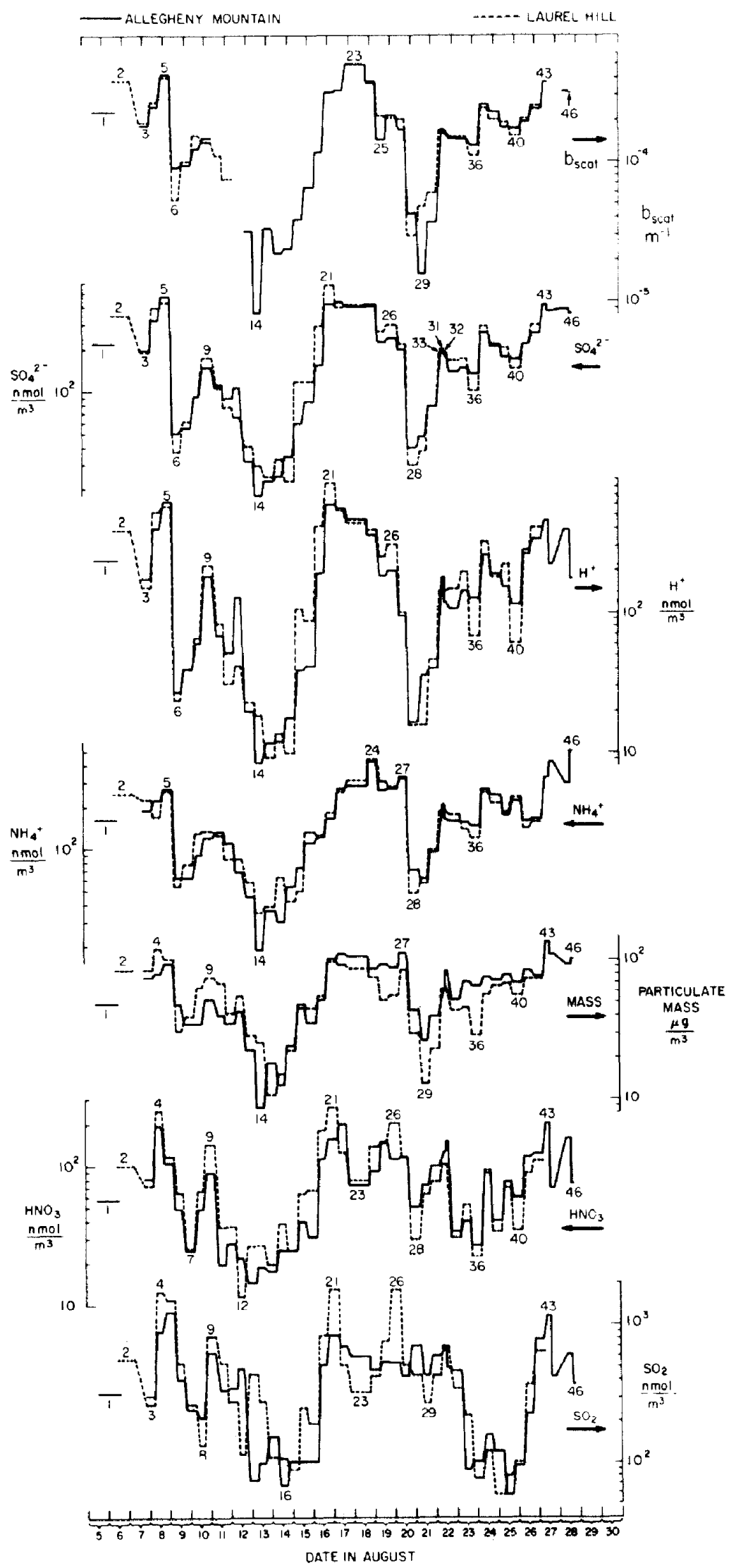

Fig. 2. Plot of run-average aerosol mass, $\mathrm{H}^{+}, \mathrm{NH}_{4}^{+}$and $\mathrm{SO}_{4}^{2-}$, the gases $\mathrm{HNO}_{3}$ and $\mathrm{SO}_{2}$, and $b_{\text {scal }}$, vs time, Allegheny Mountain and Laurel Hill, August 1983. Solid lines: Allegheny Mountain. Broken lines: Laurel Hill. Run number designations indicated are those used throughout the paper. 
Table 2. Time-average atmospheric concentrations, Allegheny Mountain and Laurel Hill, August 1983

\begin{tabular}{|c|c|c|c|c|c|c|}
\hline & \multicolumn{3}{|c|}{$\begin{array}{l}\text { Allegheny Mountain } \\
5-28 \text { August }\end{array}$} & \multicolumn{3}{|c|}{$\begin{array}{c}\text { Laurel Hill } \\
\text { 6-27 August }\end{array}$} \\
\hline & nanomole $\mathrm{m}^{-3}$ & ppb & $\mu \mathrm{g} \mathrm{m}^{-3}$ & nanomole $\mathrm{m}^{-3}$ & $\mathrm{ppb}$ & $\mu \mathrm{g} \mathrm{m}^{-3}$ \\
\hline $\mathrm{SO}_{2}$ & 409 & 11 & 26 & 490 & 13 & 31 \\
\hline $\mathrm{O}_{3}$ & 2178 & 56 & 105 & - & - & - \\
\hline $\mathrm{NH}_{3}$ & a & a & a & a & a & a \\
\hline NO & 11 & 0.3 & 0.3 & $b$ & $\mathrm{~b}$ & b \\
\hline $\mathrm{NO}_{2}+\mathrm{PAN}$ & 220 & 5.7 & & $(316)^{\mathrm{b}}$ & $(8.1)^{b}$ & \\
\hline PAN & $46^{\circ}$ & $1.2^{\mathrm{c}}$ & $6^{\mathrm{c}}$ & - & - & - \\
\hline $\mathrm{HNO}_{3}$ & 71 & 1.8 & 4.5 & 85 & 2.2 & 5.3 \\
\hline Aerosol Total Mass & & & $64^{d, 0}$ & & & $59^{\mathrm{d}, \mathrm{f}}$ \\
\hline $\mathrm{H}^{+}$ & 193 & & 0.2 & 216 & & 0.2 \\
\hline $\mathrm{NH}_{4}^{+}$ & 173 & & 3.1 & 171 & & 3.1 \\
\hline $\mathrm{NO}_{3}^{-}$ & $8^{\mathrm{k}}$ & & $0.5^{\mathrm{s}}$ & $10^{8}$ & & $0.6^{8}$ \\
\hline $\mathrm{SO}_{4}^{2-}$ & 195 & & 18.7 & 206 & & 19.8 \\
\hline Other S & $15^{\mathrm{n}}$ & & $0.5^{\mathrm{h}}$ & $21^{\mathrm{h}}$ & & $0.7^{\mathrm{h}}$ \\
\hline $\mathrm{Cl}$ & 3 & & 0.1 & 2 & & 0.08 \\
\hline C elemental & $102^{i}$ & & 1.2 & $116^{i}$ & & 1.4 \\
\hline organic & $169^{i}$ & & 2.0 & $188^{i}$ & & 2.3 \\
\hline $\mathrm{Na}$ & $3.9^{\mathrm{j}}$ & & $0.089^{j}$ & $3.4^{j}$ & & $0.079^{\mathrm{j}}$ \\
\hline $\mathbf{M g}$ & $2.8^{3}$ & & $0.069^{\prime}$ & $2.8^{\prime}$ & & $0.068^{i}$ \\
\hline Al & $15.8^{j}$ & & $0.43^{i}$ & $15.9^{i}$ & & $0.43^{\mathrm{i}}$ \\
\hline $\mathrm{Si}$ & $57.2^{j}$ & & $1.61^{\mathrm{j}}$ & $55.6^{3}$ & & $1.56^{\mathrm{i}}$ \\
\hline $\mathbf{K}$ & $3.6^{j}$ & & $0.142^{j}$ & $3.5^{\mathrm{j}}$ & & $0.136^{\mathrm{j}}$ \\
\hline $\mathrm{Ca}$ & $7.00^{\mathrm{j}}$ & & $0.28^{j}$ & $7.06^{\mathrm{j}}$ & & $0.28^{\mathrm{j}}$ \\
\hline $\mathrm{Fe}$ & $4.9^{j}$ & & $0.27^{\mathrm{j}}$ & $5.4^{\mathrm{j}}$ & & $0.30^{\mathrm{j}}$ \\
\hline $\mathrm{Se}$ & 0.028 & & 0.0022 & 0.032 & & 0.0025 \\
\hline $\mathrm{Br}$ & 0.067 & & 0.0054 & 0.068 & & 0.0055 \\
\hline $\mathrm{Pb}$ & 0.207 & & 0.043 & 0.236 & & 0.049 \\
\hline Other elements & & & $0.13^{k}$ & & & $0.14^{k}$ \\
\hline Not attributed & & & $34^{\prime}$ & & & $27^{1}$ \\
\hline
\end{tabular}

\footnotetext{
${ }^{\mathrm{a}} \mathrm{NH}_{3}(\mathrm{~g})$ was $5, \leqslant 14, \leqslant 15$ nanomoles $\mathrm{m}^{-3}$ on the first three Allegheny runs, and $1.3,5, \leqslant 18, \leqslant 7$ nanomoles $\mathrm{m}^{-3}$ on the first four Laurel runs. No further valid $\mathrm{NH}_{3}$ data were obtained.

b Laurel NO data are questionable. This could affect $\mathrm{NO}_{2}+$ PAN values. See text.

PAN GC/ECD data were obtained only for the last half (12.5 days out of 24 days) of the experiment.

${ }^{\mathrm{d}}$ Mass in weighing room at $20^{\circ} \mathrm{C}$ and $50 \%$ r.h.

$76 \%=$ fine (MMED $\leqslant 2.5 \mu \mathrm{m})$.

f $78 \%=$ fine (MMED $\leqslant 2.5 \mu \mathrm{m})$.

${ }^{8}$ Includes particles $\leqslant 1.5 \mu \mathrm{m}$ only.

${ }^{\mathrm{h}}$ Difference between total $\mathrm{S}$ (by combustion) and $\mathrm{SO}_{4}^{2-}$. The chemical nature of the non- $\mathrm{SO}_{4}^{2-}$ aerosol $\mathrm{S}$ is not known. It is larger relative to $\mathrm{SO}_{4}^{2-}$ at the lowest $\mathrm{SO}_{4}^{2-}$ concentrations.

'Nanugram-atoms $\mathrm{Cm}^{-3}$.

${ }^{i}$ Mostly coarse $(\geqslant 2.5 \mu \mathrm{m})$.

'P, Sc, Ti, V, Cr, Mn, Co, Ni, Cu, Zn, Ga, As, Rb, Sr, Zr, Mo, Ag, Cd, In, Sb, I, Cs, Ba, La, Ce, Sm, $\mathrm{Eu}, \mathrm{Dy}, \mathrm{Tm}, \mathrm{Lu}, \mathrm{Hf}, \mathrm{Ta}, \mathrm{W}, \mathrm{Au}, \mathrm{Hg}$, Th.

${ }^{1}$ Probably chiefly water at $50 \%$ weighing-room humidity. See text.
}

trailing part. Such behavior is not obvious at other times in this study or in the 1977 study. The episode began with local stagnation and continued with advection from the west, ending with fast-moving air from the NW.

The $\mathrm{SO}_{4}^{2-} /\left(\mathrm{SO}_{2}+\mathrm{SO}_{4}^{2-}\right)$ ratio was higher at $\mathrm{Al}-$ legheny than at Laurel, both in the night runs (average ratio 0.29 at Allegheny vs 0.26 at Laurel) and in the day runs (Allegheny 0.33 vs Laurel 0.29). These results would be consistent with $\mathrm{SO}_{2} \rightarrow \mathrm{SO}_{4}^{2-}$ conversion and/or $\mathrm{SO}_{2}$ dry deposition in transit from Laurel to Allegheny. The existence of approximately $30 \%$ of the $\mathrm{SO}_{2}+\mathrm{SO}_{4}^{2-}$ as $\mathrm{SO}_{4}^{2-}$ suggests that considerable conversion has already taken place, and hence suggests a considerable aging time for the $\mathrm{SO}_{4}^{2-}$ aerosol. To the extent that the $\mathrm{SO}_{2}$ has been augmented by highly localized (in time, and hence also in space) $\mathrm{SO}_{2}$ puffs, as illustrated by the spikes in Fig. 4, the conversion corrected for these local $\mathrm{SO}_{2}$ puffs would be higher still. The substantial $\mathrm{O}_{3}$ at Allegheny signifies an oxidizing condition conducive to the formation of $\mathrm{HNO}_{3}$ and $\mathrm{H}_{2} \mathrm{SO}_{4}$ from atmospheric $\mathrm{NO}_{x}$ and $\mathrm{SO}_{2}$ precursors. The high $\mathrm{NO}_{2} / \mathrm{NO}$ ratios and significant PAN and $\mathrm{HNO}_{3}$ concentrations are indicative of the same and support the perception of a polluted air mass that has undergone some photochemical aging.

Carbon, though a small part of the aerosol mass, was a leading chemical component on an atom basis; hence its inclusion in Table 2. Some of the organic carbon probably consists of gas-phase compounds 


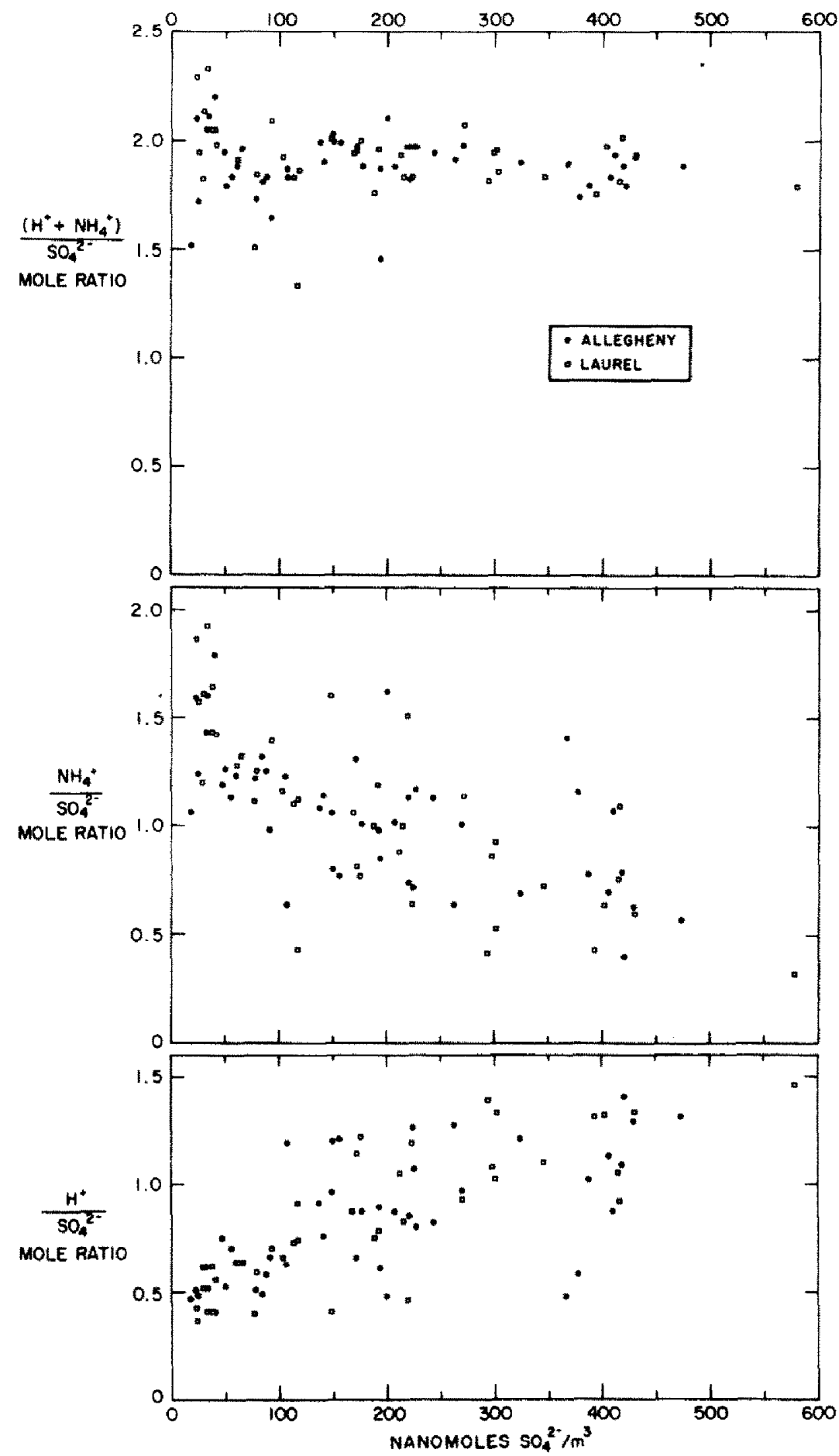

Fig. 3. Plot of aerosol $\mathrm{H}^{+} / \mathrm{SO}_{4}^{2-}$ and $\mathrm{NH}_{4}^{+} / \mathrm{SO}_{4}^{2-}$ mole ratios, and their sum $\left(\mathrm{H}^{+}+\mathrm{NH}_{4}^{+}\right) / \mathrm{SO}_{4}^{2-}$, as a function of aerosol $\mathrm{SO}_{4}^{2-}$ concentration, Allegheny Mountain and Laurel Hill, August 1983. Filled circles $=$ Allegheny Mountain data. Open squares $=$ Laurel Hill data.

adsorbed onto the quartz fibers of the HiVol filters (Cadle et al., 1983) during aerosol sampling.

The aerosol mass not recorded in Table 2 probably was chiefly water. At the $50 \%$ r.h. of the weighing room, an aqueous $\mathrm{H}_{2} \mathrm{SO}_{4}$ solution in vapor-pressure equilibrium with the air is $43.1 \% \mathrm{H}_{2} \mathrm{SO}_{4}$ by mass (Stokes and Robinson, 1949). The vapor pressure lowering by $\left(\mathrm{NH}_{4}\right)_{2} \mathrm{SO}_{4}$ or $\mathrm{NH}_{4} \mathrm{HSO}_{4}$ per mole is only slightly less than that by $\mathrm{H}_{2} \mathrm{SO}_{4}$. The water estimated by this means would account for $71 \%$ of the 


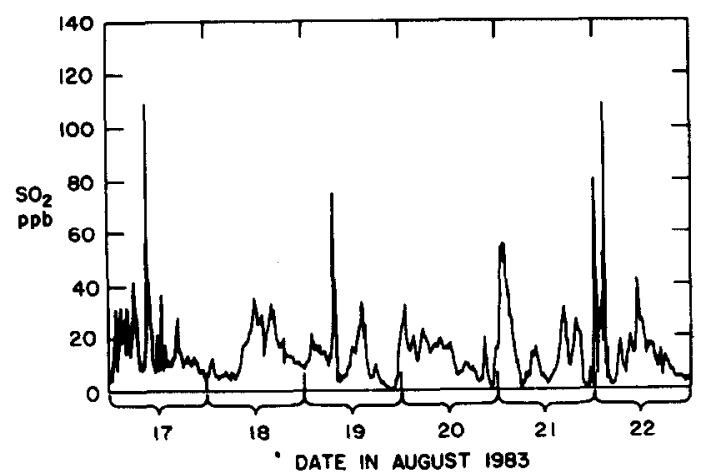

Fig. 4. A section of the record of $\mathrm{SO}_{2}$ concentrations measured continuously by pulsed u.v. fluorescence at Allegheny Mountain, August 1983.

unrecorded mass at Allegheny and $96 \%$ at Laurel. Another $10 \%$ of the unrecorded mass is implied by the trace elements-i.e. for $\mathrm{Si}$ one can assume $\mathrm{SiO}_{2}$, for $\mathrm{Ca}$ perhaps $\mathrm{CaO}$ or $\mathrm{CaCO}_{3}$, etc.

Qualitative evidence for the contribution of water to the aerosol mass comes from the nephelometry measurements. When the nephelometer incoming air was cooled by $\sim 5^{\circ} \mathrm{C}$ by turning off the inlet heater, $b_{\text {scat }}$ increased by a factor of 1.2 in clear air at $67 \%$ r.h. and by a factor of 1.6 in cloud at $92 \%$ r.h. Even without the inlet heater, the air in the nephelometer exit (and hence in the cell) was still 4 or $5^{\circ} \mathrm{C}$ above ambient temperature. Therefore there apparently was enough water in the aerosol in situ to contribute substantially to the light scattering. The effect is at least qualitatively consistent with summertime measurements in the Shenandoah Valley where much of the light scattering was traceable to $\mathrm{SO}_{4}^{2-}$-associated water (Ferman et al., 1981; Weiss et al., 1982).

Concentration spikes, of half-width sometimes only a few min, were exhibited by $\mathrm{SO}_{2}$ (Fig. 4) and by NO, $\mathrm{NO}_{2}$ and $\mathrm{CNC}$, traversing one or the other (seldom both) of the two sites. Given the surface wind speeds in Table 1, the spatial dimension corresponding to a 5 min spike is only $\sim 1 \mathrm{~km}$. There were four $\mathrm{SO}_{2}$ spikes at Allegheny, and ten at Laurel, with peak 2-min averages between 80 and $459 \mathrm{ppb}$. Most of them were $<20 \mathrm{~min}$ half-width, the shortest being $5 \mathrm{~min}$. They were predominantly associated with surface winds from the west $\left(276 \pm 63^{\circ} \mathrm{T}\right)$ and were accompanied by $\mathrm{NO}_{x}$ spikes of amplitude between 9 and $163 \mathrm{ppb}$, predominantly $\mathrm{NO}_{2}$ at the lower $\mathrm{NO}_{x}$ concentrations but reaching $\mathrm{NO} / \mathrm{NO}_{2}=1$ at the highest $\mathrm{NO}_{x}$ level. These $\mathrm{SO}_{2} / \mathrm{NO}_{x}$ spikes sometimes were accompanied by an $\mathrm{O}_{3}$ deficit spike but not much change in $\mathrm{CNC}$. None of these large $\mathrm{SO}_{2}$ spikes occurred between 0930 and 1650 (EDT); one interpretation would be that the spikes result from poorly dispersed power plant plumes injected and transported above the surface mixing layer.

$\mathrm{NO}$ and $\mathrm{NO}_{2}$ spikes often occurred together, usually with $\mathrm{NO} / \mathrm{NO}_{2} \leqslant 0.15$ and with half-width $\leqslant 10 \mathrm{~min}$, a few as short as $2 \mathrm{~min}$ FWHM. There were $14 \mathrm{NO}_{x}$ spikes at Allegheny, and 23 at Laurel, with peak 2-min averages between 40 and $163 \mathrm{ppb}$. Many were not accompanied by $\mathrm{SO}_{2}$ spikes. Only 3 of the 37 occurred between 0910 and 1840 (EDT). The NO spikes are estimated to have accounted for over half of the NO at Allegheny during the study. The largest $\mathrm{NO}_{x}$ spikes were of three types. One type, seen primarily at Allegheny, was associated with surface winds from the ESE octant and was accompanied by a CNC spike and by an equally sharp deficit spike of $\mathrm{O}_{3}$, but never an $\mathrm{SO}_{2}$ spike. Such spikes accounted for $\sim 70 \%$ of the run-average $\mathrm{NO}_{x}$ in one run (run 38, night of 24 August, $694 \mathrm{~min}$ long) at Allegheny. The second type, seen at either site, was the same as the first but was associated with surface winds from the opposite direction $\left(303 \pm 17^{\circ} \mathrm{T}\right)$. For both types, the $\mathrm{O}_{3}$ was suppressed, occasionally to as low as $2 \mathrm{ppb}$. The third type, and the most prevalent at Laurel, was associated with surface winds from the west $\left(278 \pm 40^{\circ} \mathrm{T}\right)$ and were accompanied by enormous $\mathrm{SO}_{2}$ spikes-usually $\sim 2.5$ times as large (in ppb) as the $\mathrm{NO}_{x}$. This type was not represented among the larger $\mathrm{NO}_{x}$ spikes at Allegheny. (None of the largest $14 \mathrm{NO}_{x}$ peaks at Allegheny had an $\mathrm{SO}_{2}$ peak associated with them.)

The one obvious nearby $\mathrm{NO}_{x}$ source to the ESE at each site is the Turnpike traffic, which fits the description of the first type of $\mathrm{NO}_{x}$ spikes; indeed, on most mornings at Allegheny there was an order-of-magnitude $(\sim 1 \mathrm{ppb})$ increase in hourly-average $\mathrm{NO}$ accompanied by an increase (also $\sim 1 \mathrm{ppb}$ ) in $\mathrm{NO}_{2}$. This in turn suggests Turnpike traffic as responsible for the similar $\mathrm{NO}_{x}$ spikes from the opposite direction (WNW). The third type of $\mathrm{NO}_{x}$ spikes and the accompanying $\mathrm{SO}_{2}$ spikes are ascribed to plumes from the several large power plants in the vicinity (Fig. 1).

None of the largest $\mathrm{SO}_{2}$ or $\mathrm{NO}_{x}$ spikes was accompanied by any discernible change in $b_{\text {scar. }}$. This implies that the aerosol responsible for the light scattering is not directly emitted from the sources of the $\mathrm{SO}_{2}$ or $\mathrm{NO}_{x}$ spikes.

The mid-day u.v. intensities and relative concentrations of $\mathrm{O}_{3}, \mathrm{NO}$ and $\mathrm{NO}_{2}$ at Allegheny are in reasonable accord with the photostationarity condition. At Laurel, there are questions about the NO data. In addition, $\mathrm{O}_{3}$ was not measured there, so that the NO data cannot be validated against the photostationarity criterion. Accordingly, we have opted to ignore the Laurel NO data. (Since $\mathrm{NO}_{2}+\mathrm{PAN}$ is a difference measurement between $\mathrm{NO}_{x}$ and NO, a small percentage error in $\mathrm{NO}_{2}+$ PAN at Laurel is implied.)

\section{Diurnal variability}

Night/day ratios, and night and day averages, are listed in Table 3. For wind speed, $b_{\text {seat }}$, condensation nuclei count (CNC), $\mathrm{O}_{3}, \mathrm{NO}, \mathrm{NO}_{2}+\mathrm{PAN}, \mathrm{PAN}$ and $\Sigma\left(\mathrm{NO}+\mathrm{NO}_{2}+\mathrm{PAN}\right)$, all-day averages and all-night averages of all data from the continuous monitoring were used. For each of the other variables it was 
Table 3. Diurnal variations, night/day ${ }^{a}$, Allegheny Mountain and Laurel Hill, August 1983. Night and day time-weighted averages are given in parentheses, in the dimensions indicated

\begin{tabular}{|c|c|c|}
\hline & Allegheny & Laurel \\
\hline Surface wind speed $\left(\mathrm{ms}^{-1}\right)$ & $1.1(4.1 / 3.7)$ & $1.0(3.1 / 3.0)$ \\
\hline$b_{\text {scat }}\left(10^{-4} \mathrm{~m}^{-1}\right)$ & $1.0^{\mathrm{b}}(1.9 / 1.9)$ & $1.1^{\mathrm{b}}(1.9 / 1.8)$ \\
\hline $\mathrm{CNC}\left(\mathrm{cm}^{-3}\right)$ & $0.7(4700 / 6700)$ & \\
\hline $\mathrm{SO}_{2}\left(\mathrm{nmol} \mathrm{m}^{-3}\right)$ & $1.05(823 / 783)$ & $1.2(1057 / 895)$ \\
\hline $\mathrm{O}_{3}\left(\mathrm{nmol} \mathrm{m}^{-3}\right)$ & $0.95(2067 / 2168)$ & $\ldots$ \\
\hline $\mathrm{NO}\left(\mathrm{nmol} \mathrm{m}^{-3}\right)$ & $0.3(6 / 18)$ & c \\
\hline $\mathrm{NO}_{2}+\mathrm{PAN}\left(\mathrm{nmol} \mathrm{m}^{-3}\right)$ & $1.3(286 / 219)$ & $(1.0(355 / 339))^{\mathrm{c}}$ \\
\hline PAN (nmol m $\left.{ }^{-3}\right)$ & $0.8(41 / 49)$ & - \\
\hline$\Sigma\left(\mathrm{NO}+\mathrm{NO}_{2}+\mathrm{PAN}\right)\left(\mathrm{nmol} \mathrm{m}^{-3}\right)$ & $1.2(292 / 237)$ & $1.0(414 / 404)$ \\
\hline $\mathrm{HNO}_{3}\left(\mathrm{nmol} \mathrm{m}^{-3}\right)$ & $0.7(64 / 86)$ & $0.9(80 / 89)$ \\
\hline Aerosol mass, coarse $\left(\mu \mathrm{g} \mathrm{m}^{-3}\right)$ & $1.3(17 / 13)$ & $1.1(12.5 / 11)$ \\
\hline fine $\left(\mu \mathrm{g} \mathrm{m}^{-3}\right)$ & $0.8(42 / 54)$ & $0.9(40 / 46)$ \\
\hline $\mathrm{H}^{+}\left(\mathrm{nmol} \mathrm{m}^{-3}\right)$ & $0.9(168 / 178)$ & $1.0(189 / 190)$ \\
\hline $\mathrm{NH}_{4}^{+}\left(\mathrm{nmol} \mathrm{m}^{-3}\right)$ & $0.9(158 / 178)$ & $1.1(160 / 150)$ \\
\hline $\mathrm{NO}_{3}^{-}\left(\mathrm{nmol} \mathrm{m}^{-3}\right)$ & $1.6(9 / 6)$ & $1.3(11 / 9)$ \\
\hline $\mathrm{SO}_{4}^{2-}\left(\mathrm{nmol} \mathrm{m}^{-3}\right)$ & $0.9(342 / 377)$ & $1.0(368 / 360)$ \\
\hline Other $\mathrm{S}\left(\mathrm{nmol} \mathrm{m}^{-3}\right)$ & $0.7(28 / 41)$ & $0.8(39 / 51)$ \\
\hline $\mathrm{C}$ elemental $\left(\mu \mathrm{g} \mathrm{m}^{-3}\right)$ & $1.1(1.24 / 1.14)$ & $1.0(1.31 / 1.37)$ \\
\hline organic $\left(\mu \mathrm{g} \mathrm{m}^{-3}\right)$ & $0.8(1.91 / 2.27)$ & $1.0(2.27 / 2.31)$ \\
\hline
\end{tabular}

\footnotetext{
${ }^{a}$ For wind speed, $b_{\text {scat }}, \mathrm{CNC}, \mathrm{O}_{3}, \mathrm{NO}, \mathrm{NO}_{2}+\mathrm{PAN}, \mathrm{PAN}$, and $\Sigma\left(\mathrm{NO}+\mathrm{NO}_{2}\right.$ + PAN), all night-time ( $\equiv 2000$ to $0700 \mathrm{EDT}$ ) and daytime ( $\equiv 0700$ to $2000 \mathrm{EDT}$ ) data from the continuous monitoring were used. For everything else, timeweighted averages of night-time runs and of daytime runs (two Allegheny runs and two Laurel runs were excluded as covering longer periods) were used.

${ }^{b}$ Heated nephelometer inlet. Cell temperature is $\sim 15^{\circ} \mathrm{C}$ above ambient.

${ }^{\mathrm{c}}$ Laurel NO data are questionable. This could affect $\mathrm{NO}_{2}+$ PAN values. See text.
}

necessary to use the time-weighted average from the night-time runs and the time-weighted average from the daytime runs; two long runs at Allegheny and two at Laurel were excluded as falling into neither category, and hence the overall averages in Table 2 do not always fall between the night and day averages in Table 3 . When a ratio differs significantly from unity, then obviously the diurnal peak/valley ratio exceeded the ratio given in Table 3 . Representative diurnal variations constructed from continuous data for certain of the species are illustrated in Fig. 5. Composite valley/peak ratios include 0.4 for $\mathrm{PAN}$ and 0.8 for $\mathrm{O}_{3}$ (night/day, Fig. 5), 0.4 for CNC (night/day), 0.8 for wind speed (day/night).

The large diurnal variation in NO (Fig. 5) is basically as expected: Oxidation of NO by the considerable excess of $\mathrm{O}_{3}$ proceeds all the time while $\mathrm{NO}_{2}$ photolysis is arrested at night. In addition, however, there was an order-of-magnitude NO excursion on most mornings, reaching a maximum at about 1000 EDT (Fig. 5). Much or most of the $\mathrm{NO}_{x}$ peak $\left(\mathrm{NO}+\mathrm{NO}_{2}\right.$ + PAN, Fig. 5) occurring at that time consisted of NO. Concurrently there was an $\mathrm{O}_{3}$ minimum (Fig. 5), deeper in terms of ppb than the increase in $\mathrm{NO}_{x}$ or NO. The surface mixing layer is building up at that time, perhaps allowing NO emitted and stored overnight at lower elevation to reach the site, its rapid conversion to $\mathrm{NO}_{2}$ upon mixing with the $\mathrm{O}_{3}$ being offset somewhat by $\mathrm{NO}_{2}$ photolysis.
Total $\mathrm{NO}_{x}$ had a pronounced diurnal maximum at around 2100 EDT consisting wholly of an increase in $\mathrm{NO}_{2}$ with little or no change in NO or PAN (Fig. 5). The upslope coincided more or less with the collapse of the daytime mixing layer, and is interpreted as signifying the confinement of $\mathrm{NO}_{x}$ emissions to the increasingly thinner layer. The downside of the peak would then set in as the nocturnal surface inversion forms below the mountaintop and air that is cut off from ground-level emissions begins to be sampled. The wide daytime valley in the $\mathrm{NO}_{x}$ concentration (between the 1000 and 2100 peaks) is then a reflection of dilution attending the evolution of the mixing layer.

PAN declined during the night-presumably because its photochemical production ceases while its thermal dissociation continues-with a decay half-life of 7 to $8 \mathrm{~h}$ (Fig. 5). The PAN diurnal maxima and minima were at about 1800 and 0830 EDT, respectively.

$\mathrm{HNO}_{3}$ was lower at night presumably because its photochemical production stopped. The relatively small diurnal change compared, for example, to the situation in the Los Angeles basin (Pierson et al., 1988) indicates that most of the $\mathrm{HNO}_{3}$ is transported to the site rather than locally formed. Meanwhile, at night aerosol $\mathrm{NO}_{3}^{-}$increased, possibly because of the gas/ particle equilibrium effects of humidity and temperature. The low $\mathrm{HNO}_{3}$ deposition velocity found in the present experiment under stratified night-time condi- 


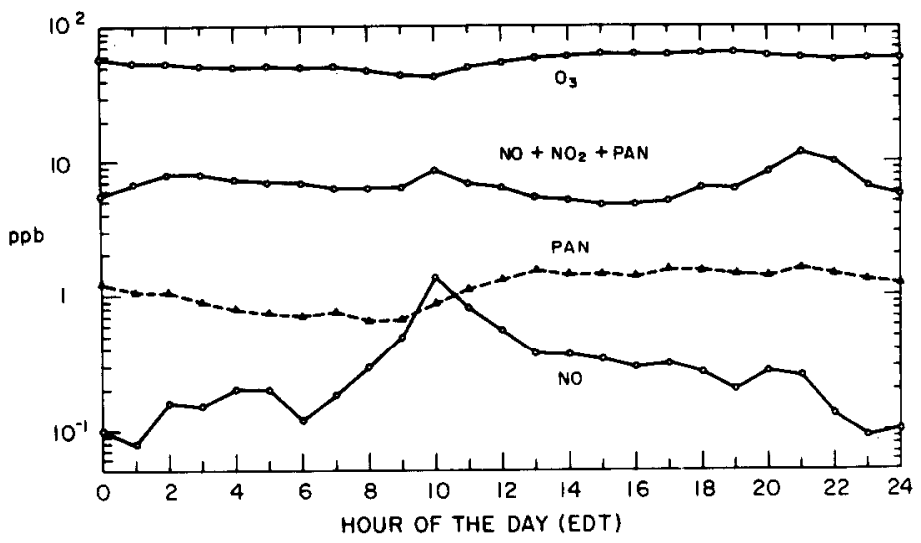

Fig. 5. Diurnal variations of $\mathrm{O}_{3}, \mathrm{PAN}, \mathrm{NO}$ and " $\mathrm{NO}_{x}$ " $\left(\equiv \mathrm{NO}+\mathrm{NO}_{2}\right.$ + PAN) representing the composite of hourly averages of continuous data for the entire study, Allegheny Mountain, August 1983.

tions (0.24 $\mathrm{cm} \mathrm{s}^{-1}$; Pierson et al., 1986), in contrast to order-of-magnitude higher daytime values, suggests that long-distance transport of $\mathrm{HNO}_{3}$ at night is possible.

The CNC diurnal pattern (not illustrated), with a flat minimum from 0000 to 0900 followed by build-up to a peak around 1230 , appears consistent with photochemical production. The u.v. peak was at 1400 EDT.

The $\mathrm{SO}_{4}^{2-} /\left(\mathrm{SO}_{2}+\mathrm{SO}_{4}^{2-}\right)$ ratio was $10 \%$ lower at night than in the daytime, at both sites, mostly because the daytime ratio was raised by an afternoon subsidence in the $\mathrm{SO}_{2}$ concentration. This subsidence, commencing around noon, is almost a mirror image of the afternoon $\mathrm{O}_{3}$ enhancement. But there was little, if any, corresponding increase in $b_{\text {scat }}$ (hence, in real-time $\mathrm{SO}_{4}^{2-}$ ). Because of dilution effects attending changes in mixing depth, and because of the possibility of enhanced $\mathrm{SO}_{2}$ dry deposition from the unstable afternoon atmosphere, these observations argue neither for nor against a significant local daytime component in the $\mathrm{SO}_{2} \rightarrow \mathrm{SO}_{4}^{2-}$ conversion.

We did not see any daytime increase in $\mathrm{H}^{+} / \mathrm{SO}_{4}^{2-}$ ratio or in $\mathrm{H}^{+} / \mathrm{NH}_{4}^{+}$ratio at either site (Table 3). Such increases would have been indicative of daytime local $\mathrm{SO}_{2} \rightarrow \mathrm{SO}_{4}^{2-}$ conversion, and have been unequivocally seen in other work at other sites (Stevens et al., 1980, 1984; Weiss et al., 1982). Our interpretation is that the Allegheny and Laurel sites are above the surface inversion which forms in the evening so that (1) the acid aerosol is cut off from further ground-level $\mathrm{NH}_{3}$ emissions and (2) removal processes are suppressed. The lack of diurnal variation in $\mathrm{H}^{+} / \mathrm{SO}_{4}^{2-}$ or $\mathrm{H}^{+} / \mathrm{NH}_{4}^{+}$then means that local daytime $\mathrm{SO}_{2} \rightarrow \mathrm{SO}_{4}^{2-}$ conversion is relatively unimportant. In other words, the $\mathrm{H}^{+}, \mathrm{NH}_{4}^{+}, \mathrm{SO}_{4}^{2-}$, and their ratios, as seen at the sites are the composition of what is transported rather than what is locally generated. (If $\mathrm{SO}_{2} \rightarrow \mathrm{SO}_{4}^{2-}$ rate coefficients are of the order of $10^{-2} \mathrm{~h}^{-1}$ as generally thought, then this is plausible.)

The $\mathrm{O}_{3}$ diurnal variation (Fig. 5) was only $\sim 20 \%$ except for the minimum coinciding with the midmorn- ing NO peak. This lack of diurnal variation would be expected at high-altitude rural sites where night-time ground removal of $\mathrm{O}_{3}$ is inhibited by the night-time atmospheric stability (the sites are above the surface inversion) and NO has become depleted.

Finally, it appears that the coarse aerosol mass was higher at night than in the daytime, whereas the fine was higher in the daytime than at night. This is consistent with a slight particle-size shift with the higher r.h. that existed at night (Keeler et al., 1988).

\section{Intra-site correlations}

Table 4 lists intra-site correlation coefficients of run-average data obtained at Allegheny and at Laurel. Only those variables thought to be of importance to the present discussion are included. $\mathrm{Si}, \mathrm{Se}, \mathrm{Pb}$, and elemental $\mathrm{C}(\mathrm{EC})$-coarse plus fine in each instanceare included as candidate markers for soil dust, coal burning, automotive emissions and fuel combustion in general (including diesel trucks, woodburning, etc.), respectively; $\mathrm{V}$, a potential marker for fuel-oil burning, was omitted because it showed no significant correlation with anything else. Mn was included because its peak concentrations tended to coincide with $\mathrm{SO}_{2}$ peak concentrations.

The highest correlations are of $b_{\text {scat }}$, aerosol $\mathrm{H}^{+}$, and aerosol $\mathrm{SO}_{4}^{2-}$ with one another. Figure 6 shows that the relationship between $b_{\text {scat }}$ and $\mathrm{SO}_{4}^{2-}$ is linear. The variance in one accounts for some $92 \%\left(r^{2}=0.92\right)$ of the variance in the other, with a slope of 8.8 $\pm 0.3 \mathrm{~m}^{2}$ per gram of $\mathrm{SO}_{4}^{2-}$. Clearly $b_{\text {scat }}$ can be used as a real-time index of aerosol $\mathrm{SO}_{4}^{2-}$. This is as expected, given the domination of the aerosol mass by $\mathrm{SO}_{4}^{2-}$ together with its associated cations and water. According to regressions of day-only runs and night-only runs, the $b_{\text {scat }} / \mathbf{S O}_{4}^{2-}$ ratio tended to be $\sim 12 \%$ higher in the night runs than in the day runs. This is qualitatively reasonable since the nephelometer cell was $\sim 6^{\circ} \mathrm{C}$ cooler at night than in the daytime and since water associated with the $\mathrm{SO}_{4}^{2-}$ was playing a role in scattering. 


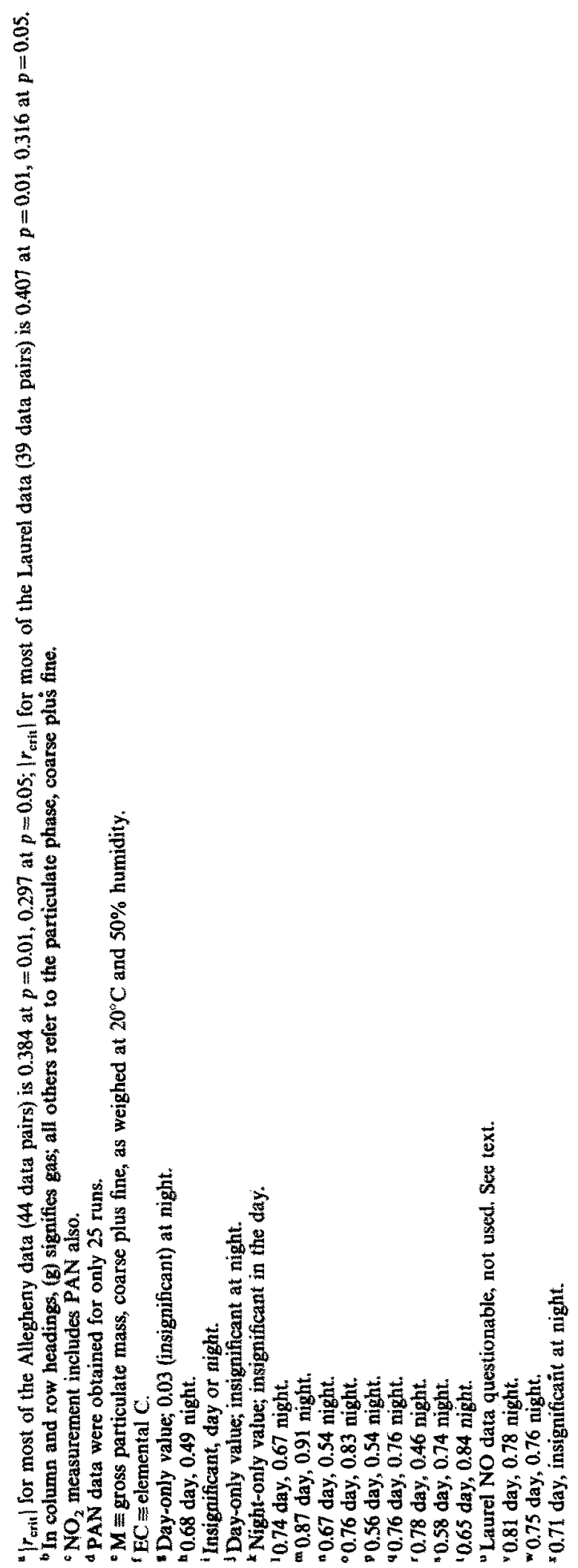




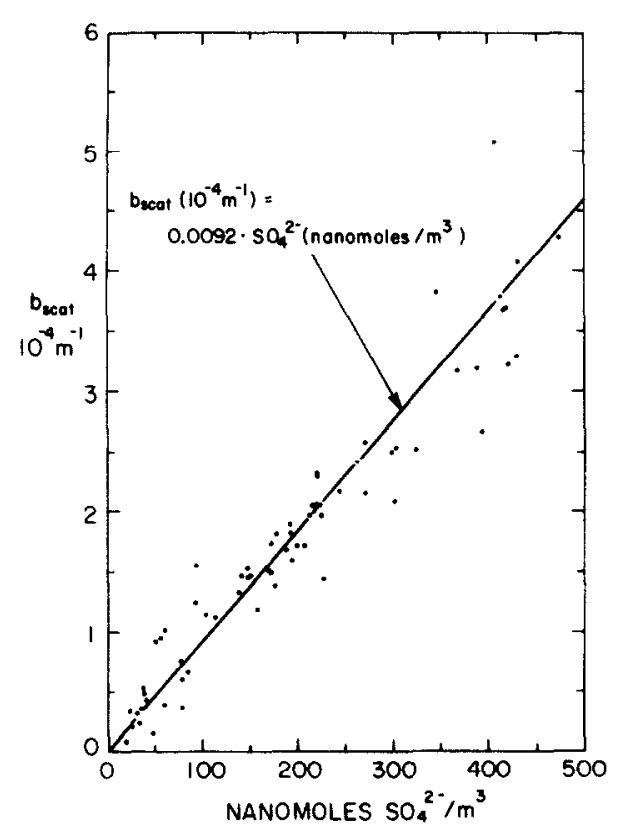

Fig. 6. Plot of run-average $b_{\text {scat }}$ vs aerosol $\mathrm{SO}_{4}^{2-}$, Allegheny Mountain and Laurel Hill combined, August 1983. The nephelometer inlet air is heated. The drawn line is a fit by eye, taking into account the uncertainties in each region. For comparison, linear least-squares regression yields $y=(0.00849$ $\pm 0.00032) \cdot x+0.124 \pm 0.075, r=0.96$

The slope $\mathrm{dH}^{+} / \mathrm{dSO}_{4}^{2-}$ (mole ratio) of the $\mathrm{H}^{+}$vs $\mathrm{SO}_{4}^{2-}$ regression line was $1.14 \pm 0.07$ at Allegheny and $1.34 \pm 0.06$ at Laurel, without a consistently signifcant night/day difference and with a very high correlation ( $r=0.93$ at Allegheny, 0.97 at Laurel). The actual relationship between aerosol $\mathrm{H}^{+}$and $\mathrm{SO}_{4}^{2-}$ is probably stronger than is implied by their correlation, first on the grounds that the $\sim \pm 10 \% \mathrm{H}^{+}$measurement uncertainty ( $\pm 0.02 \mathrm{pH}$ units) surely degraded the correlation. Second, linear regression of $\mathrm{H}^{+}$vs $\mathrm{SO}_{4}^{2-}$ is not rigorously valid in that the slope of $\mathrm{H}^{+}$vs $\mathrm{SO}_{4}^{2-}$ is not a straight line; the $\mathrm{H}^{+} / \mathrm{SO}_{4}^{2-}$ ratio is not constant but rather is a function of $\mathrm{SO}_{4}^{2-}$ concentration (Fig. 3). The same holds for $\mathrm{NH}_{4}^{+}$vs $\mathrm{SO}_{4}^{2-}$, where again $\mathrm{NH}_{4}^{+}$ is not linear in $\mathrm{SO}_{4}^{2-}$ (Fig. 3).

The partial neutralization of the light-scattering aqueous $\mathrm{H}_{2} \mathrm{SO}_{4}$ by whatever $\mathrm{NH}_{3}(\mathrm{~g})$ is available would be consistent with the lower, but still high, correlation of aerosol $\mathrm{NH}_{4}^{+}$with $b_{\text {scat }}$ or $\mathrm{SO}_{4}^{2-}(\bar{r}$ $=0.79$ ) and the significant but still lower correlation between aerosol $\mathrm{NH}_{4}^{+}$and $\mathrm{H}^{+}(\vec{r}=0.57)$. There is a correlation (though small) between aerosol $\mathrm{NO}_{3}^{-}$and $\mathrm{NH}_{4}^{+}$, qualitatively consistent with the fact that $\mathrm{H}_{2} \mathrm{SO}_{4}$ has to be mostly neutralized before significant amounts of $\mathrm{NO}_{3}^{-}$can exist in the condensed phase:

$$
\begin{aligned}
\mathrm{NH}_{3}(\mathrm{~g})+\mathrm{HNO}_{3}(\mathrm{~g}) & \rightarrow \mathrm{NH}_{4}^{+}+\mathrm{NO}_{3} \\
\mathrm{NO}_{3}^{-}+\mathrm{HSO}_{4}^{-} & \rightarrow \mathrm{HNO}_{3}(\mathrm{~g}) \uparrow+\mathrm{SO}_{4}^{2-} .
\end{aligned}
$$

The $\mathrm{SO}_{2}$ correlation to the acidic aerosol $\mathrm{H}^{+}$and $\mathrm{SO}_{4}^{2-}$ and to $b_{\text {scat }}$ was marginal $(\bar{r}=0.64)$, as was the case in 1977 (Pierson et al., 1980) when $\mathrm{SO}_{2}$ was uncorrelated to aerosol $\mathrm{SO}_{4}^{2-}(r=0.30)$. We have mentioned already that the $\mathrm{SO}_{2}$ spikes were not accompanied by any discernible change in $b_{\text {scat }}$. Given that $b_{\text {scat }}$ is an index of $\mathrm{SO}_{4}^{2-}$, it becomes clear that the $\mathrm{SO}_{2}$ and $\mathrm{SO}_{4}^{2-}$ are decoupled, both overall and in detail; i.e. most of the acrosol $\mathrm{SO}_{4}^{2-}$ is not in the $\mathrm{SO}_{2}$ plumes and does not accompany the $\mathrm{SO}_{2}$ in general. The sources responsible for the $\mathrm{SO}_{2}$ spikes are evidently near enough for only minimal $\mathrm{SO}_{2} \rightarrow \mathrm{SO}_{4}^{2-}$ conversion to have occurred. The major $b_{\text {scat }}$ features are far broader $(0.5-5 \mathrm{~h})$ than the $\mathrm{SO}_{2}$ spikes $(0.1-0.3 \mathrm{~h})$, implying a more diffuse or less localized behavior for the $\mathrm{SO}_{4}^{2-}$ aerosol.

$\mathrm{HNO}_{3}(\mathrm{~g})$ was correlated moderately $(\vec{r}=0.74)$ to $b_{\text {scat }}$ and to the acidic aerosol $\mathrm{H}^{+}$and $\mathrm{SO}_{4}^{2-}$, as well as to $\mathrm{SO}_{2}(r \simeq 0.8)$. As we have seen, $\mathrm{SO}_{2}$ is at best marginally related to $b_{\text {scat }}$ or to aerosol $\mathrm{H}^{+}$or $\mathrm{SO}_{4}^{2-}$. $\mathrm{HNO}_{3}(\mathrm{~g})$ therefore appears to be associated in part with each of the two sulfur regimes, i.e. the more local $\mathrm{SO}_{2}$ one and the less local $\mathrm{SO}_{4}^{2-}$ one. Indeed $\mathrm{Se}$, our candidate marker for coal burning, is moderately well correlated to $\mathrm{SO}_{2}$, to $b_{\text {scat }}$ and aerosol $\mathrm{H}^{+}$and $\mathrm{SO}_{4}^{2-}$, and to $\mathrm{HNO}_{3}(\mathrm{~g})$. Multiple regression of Se onto $\mathrm{SO}_{4}^{2-}$ and $\mathrm{SO}_{2}$ gave $r=0.91$ at Allegheny, 0.85 at Laurel.

$\mathrm{HNO}_{3}(\mathrm{~g})$ is correlated moderately well to $\mathrm{O}_{3}$. We take this as reflecting the photochemically oxidizing conditions under which $\mathrm{HNO}_{3}$ is expected to form.

The intercorrelations of $\mathrm{O}_{3}$ and PAN in Table 4 are consistent with photochemical activity. During the day, PAN was correlated with $\mathrm{O}_{3}(r=0.70)$. The correlation became insignificant at night $(r=0.33$; with only nine data pairs at night, $r_{\text {crit }}=0.67$ at $p$ $=0.05$ ). Examination of the continuous traces shows similarities between $\mathrm{O}_{3}$ and PAN, less at night than in the daytime. The composite diurnal patterns of $\mathrm{O}_{3}$ and PAN shown in Fig. 5 are strongly correlated $(r=0.88)$. These observations are consistent with a more-or-less local component in the $\mathrm{O}_{3}$ and PAN photochemistry.

Meanwhile, in the presence of the large excess of $\mathrm{O}_{3}$ (Table 2), an Allegheny $\mathrm{NO}$ vs $\mathrm{NO}_{2}$ correlation exists but is clear only if one deals separately with the daytime (when $\mathrm{NO}_{2}$ photodissociation can occur) and night-time (when it cannot). For the day-only and night-only run averages we have $r=0.65$ and 0.84 , respectively, for $\mathrm{NO}$ vs $\mathrm{NO}_{2}$ at Allegheny. The continuous traces show that the $\mathrm{NO}$ and $\mathrm{NO}_{2}$ are closely related.

Night-time PAN, while not correlated with $\mathrm{O}_{3}$, was significantly correlated with $b_{\text {scat }}$ and with aerosol mass, $\mathrm{H}^{+}, \mathrm{NH}_{4}^{+}$and $\mathrm{SO}_{4}^{2-}$. This is important in that PAN implies an aged polluted photochemical air mass. (However, in the daytime there were no significant correlations of run-average PAN with any variable except $\mathrm{O}_{3}$.)

There were several occasions when PAN composed most of the $\mathrm{NO}+\mathrm{NO}_{2}+\mathrm{PAN}$ sum. On those occasions the PAN trace was similar to those of $\mathrm{O}_{3}$ and $b_{\text {scat }}$. Detailed inspection of the continuous data re- 
vealed numerous instances, all between noon and midnight and lasting for 1 to $13 \mathrm{~h}$, when PAN, $\mathrm{O}_{3}$ and $b_{\text {seat }}$ all had similar patterns. Winds tended to be either omnidirectional or, more often, out of the southerly semicircle between $125^{\circ}$ and $305^{\circ}$. The several-hour widths of the peaks were in contrast to the short-lived spikes of the $\mathrm{NO}_{x}$ or $\mathrm{SO}_{2}$. These observations, together with the modest but significant correlations of run-average $b_{\text {scat }}$ with $\mathrm{O}_{3}$ and PAN (Table 4), attest to photochemical formation of at least some of the aerosol $\mathrm{SO}_{4}^{2-}$ on these occasions.

$\mathrm{NO}$ and $\mathrm{NO}_{2}$ (and $\mathrm{NO}_{x}$, not listed in Table 4) were for the most part not significantly correlated with $\mathrm{HNO}_{3}$ or $\mathrm{SO}_{2}$. They did show significant night-time run-average correlations with $\mathrm{CNC}$. The lack of correlation between $\mathrm{NO}_{x}$ and $\mathrm{SO}_{2}$ was unexpected since $70 \%$ of the $\mathrm{NO}_{x}$ from upwind areas is supposed to come from nonautomotive (hence, mostly $\mathrm{SO}_{2}$-producing) sources. Turnpike traffic may have played a role here. A difference in time scales for removal$\mathrm{NO}_{x}$ much more rapid than $\mathrm{SO}_{2}$-possibly is involved also.

Over most of the experiment, the CNC continuous trace was very similar to $\mathrm{NO}_{2}$-and not to $\mathrm{NO}$ or $\mathrm{SO}_{2}$. But by far the highest $\mathrm{CNC}$ registered in the study occurred on an exceptionally clear day (21 August) with the lowest humidity and dew point of the study, with low PAN and $\mathrm{O}_{3}$, and with no discernible relation to $\mathrm{O}_{3}, \mathrm{NO}, \mathrm{NO}_{2}, \mathrm{SO}_{2}$ or $b_{\text {scat }}$. None of these features (nor the CNC correlations in Table 4) suggest any relation of $\mathrm{CNC}$ to the acidity issue.

It is seen in Table 4 that simple regressions onto the source-marker elements, other than Se (coal-burning), are of little help in placing the origins of the acid components in the air. $\mathrm{Pb}$, the automotive marker, exhibited only indifferent correlations to the other species, and in particular an insignificant one to $\mathrm{HNO}_{3}(\mathrm{~g})$ and the other $\mathrm{NO}_{x}$ and $\mathrm{NO}_{x}$-derived species (Table 5). On the other hand, the ratio between studyaverage $\Sigma\left(\mathrm{NO}+\mathrm{NO}_{2}+\mathrm{PAN}+\mathrm{HNO}_{3}\right)$ and studyaverage $\mathrm{Pb}, 1388$ moles $\left(\mathrm{g}\right.$-atom ${ }^{-1}$ ), is only perhaps twice the all-vehicle automotive $\mathrm{NO}_{x} / \mathrm{Pb}$ ratio; thus the automotive portion of the $\Sigma\left(\mathrm{NO}+\mathrm{NO}_{2}+\mathrm{PAN}\right.$ $+\mathrm{HNO}_{3}$ ) may have been significant.

The high correlations of EC with some of the acidity components in Table 4 probably do not imply a common source for the two, since EC correlations with $\mathrm{SO}_{2}$ or Se are not very strong. It is likely that the EC is just a concomitant of the generally polluted aged air mass in which these acidic species evolve.

In the 1977 Allegheny experiment we found aerosol $\mathrm{NO}_{3}^{-}$to be correlated to $\mathrm{Mg}$ and $\mathrm{Ca}(r=0.69$ each), essentially alone of all species measured, and we ascribed the correlation to scavenging of $\mathrm{HNO}_{3}$ by alkaline particles containing, e.g. $\mathrm{CaCO}_{3}$, either in the air or on the accumulating filter deposit. In the present study no correlation was found $(r \leqslant 0.2)$; but only the aerosol $\mathrm{NO}_{3}^{-}$finer than $1.5 \mu \mathrm{m}$ was measured in the present study, whereas the $\mathrm{Mg}$ and $\mathrm{Ca}$ were found to be predominantly in large particles $(\mathrm{MMED}=4$ or
$5 \mu \mathrm{m})$. While $\mathrm{HNO}_{3}$ reactions may have occurred as formerly proposed, this could not have affected the present (fine-particle) aerosol $\mathrm{NO}_{3}^{-}$measurement very much. Thus the correlation of aerosol $\mathrm{NO}_{3}^{-}$with $\mathrm{Mg}$ and $\mathrm{Ca}$ in 1977, and the contrary result in the present study, could both be correct, accounted for by particle-size measurement differences. It is known (Wolff, 1984) that summertime aerosol $\mathrm{NO}_{3}^{-}$in the eastern U.S. is predominantly in the coarse size fraction owing, evidently, to reaction of atmospheric $\mathrm{HNO}_{3}(\mathrm{~g})$ with airborne soil dust.

\section{Inter-site correlations}

Table 6 shows strong inter-site correlations of the variables related to aerosol acidity-that is, $b_{\text {scat }}$ and aerosol $\mathrm{H}^{+}, \mathrm{NH}_{4}^{+}$and $\mathrm{SO}_{4}^{2-}(\bar{r}=0.96)$. The 'real' $\mathrm{H}^{+}$ inter-site correlation is probably better than that shown, because of the $\mathrm{H}^{+}$measurement uncertainty. Aerosol fine mass is largely related to $\mathrm{SO}_{4}^{2-}$ and therefore its inter-site correlation is fairly high - again adversely affected by measurement errors.

These high correlations imply dimensions $\gg 35 \mathrm{~km}$ for the acid aerosol 'blob'. The situation is quite evident in the continuous $b_{\text {scat }}$ traces, which are very similar at the two. sites. Typically a given feature appearing at Laurel develops concurrently at Allegheny or arrives essentially unaltered at Allegheny an hour or so later.

The $\mathrm{HNO}_{3}(\mathrm{~g})$ inter-site correlations at night and in the day are $r=0.88$ and 0.82 , respectively. The intersite correlations for total inorganic $\mathrm{NO}_{3}^{-}\left(\mathrm{HNO}_{3}(\mathrm{~g})\right.$ + aerosol $\mathrm{NO}_{3}^{-}$) are $r=0.87$ and 0.83 night and day, respectively.

The moderate $\mathrm{SO}_{2}(\mathrm{~g})$ inter-site correlation $(r=0.75$ night, $\mathbf{0 . 8 0}$ day) is consistent with its more local scale as exemplified by the fact that high $\mathrm{SO}_{2}$ concentrations observed at one site usually miss the other. Inspection of the $\mathrm{SO}_{2}$ continuous traces reveals that there is actually a fair amount of similarity between the two sites but with usually a time shift of 1 to $4 \mathrm{~h}$, which of course destroys the correlation to the extent that features narrower than several hours are involved. The time shifts are generally consistent with the wind speeds and directions, i.e. transport. Basically there are three types of $\mathrm{SO}_{2}$ features, namely, (1) the spikes, which usually do not match up well between the sites, (2) peaks and valleys a few hours wide, which match more often, and (3) broad features of the time scale of a day which, on the few occasions when they are seen, are clearly reproduced at both sites.

Finally, the $\mathrm{NO}_{x}$ inter-site correlation is quite poor, for four reasons revealed in the continuous $\mathrm{NO}_{x}$ traces. (1) The $\mathrm{NO}_{x}$ spikes at one site seldom have a counterpart at the other and, when they do, the time shift exceeds the spike width so the correlation is degraded rather than enhanced. (2) Even when the spikes are simultaneous the amplitudes are nearly always vastly different; sometimes the weaker one was the upwind one, in which cases impact parameter must have been important as opposed to chemistry during 
Table 5. Correlation coefficients $(r)$ between run-average $\mathrm{Pb}$ and oxidized $\mathrm{N}$ species, Allegheny Mountain and Laurel Hill, August 1983. Data are arranged in pairs; top $=r$ at Alleghe$n y$, bottom $=r$ at Laurel. Values in parentheses are not significant at the $99 \%$ confidence leve ${ }^{\mathrm{a}}$

\begin{tabular}{lcc}
\hline & $\begin{array}{c}\mathrm{Pb} \\
\text { Fine }\end{array}$ & $\begin{array}{c}\mathrm{Pb} \\
\text { Total }\end{array}$ \\
\hline $\mathrm{NO}$ & $(-0.13)$ & $(-0.13)$ \\
& $(0.22)$ & $(0.38)$ \\
$\mathrm{NO}_{2}+\mathrm{PAN}^{\mathrm{c}}$ & 0.45 & 0.46 \\
$\mathrm{NO}+\mathrm{NO}_{2}+\mathrm{PAN}^{\mathrm{c}}$ & $(0.20)$ & $(0.35)$ \\
$\mathrm{HNO}_{3}{ }^{\mathrm{d}}$ & $(0.40)$ & 0.42 \\
$\mathrm{NO}+\mathrm{NO}_{2}+\mathrm{PAN}^{+} \mathrm{HNO}_{3}$ & $(0.37)$ & $(0.34)$ \\
& $(0.36)$ & $(0.37)$ \\
& $0.33)$ & 0.46 \\
& 0.44 & 0.46 \\
\hline
\end{tabular}

${ }^{\mathrm{a}}\left|r_{\mathrm{c} \text { rit }}\right|$ for $p=0.01$ is 0.384 at Allegheny, 0.407 at Laurel.

b Laurel NO data questionable, not used. See text.

${ }^{c}$ Chemiluminescence $\mathrm{NO}_{2}$ and $\mathrm{NO}_{x}$ measurements include PAN.

${ }^{d} \mathrm{HNO}_{3}$ from denuder-difference measurements.

Table 6. Inter-site correlation coefficients $(r)^{2}$ between Allegheny Mountain and Laurel Hill data, August 1983

\begin{tabular}{|c|c|}
\hline$b_{\mathrm{scal}}$ & $0.969^{b}$ \\
\hline $\mathrm{SO}_{2}$ & 0.754 \\
\hline $\mathrm{NO}_{x}$ & $(0.464)^{\mathrm{c}}$ \\
\hline $\mathrm{HNO}_{3}$ & 0.810 \\
\hline Aerosol mass, coarse & 0.685 \\
\hline fine & 0.798 \\
\hline total & 0.784 \\
\hline $\mathrm{H}^{+}$ & 0.945 \\
\hline $\mathrm{NH}_{4}^{+}$ & 0.975 \\
\hline $\mathrm{NO}_{3}^{-}$ & 0.669 \\
\hline $\mathrm{SO}_{4}^{2-}$ & 0.959 \\
\hline C elemental & 0.829 \\
\hline organic & 0.807 \\
\hline Soil elements ${ }^{d}$ & 0.899 \\
\hline $\mathrm{V}$ & 0.967 \\
\hline Mn & 0.941 \\
\hline $\mathrm{Se}$ & 0.876 \\
\hline $\mathrm{Br}$ & 0.737 \\
\hline $\mathrm{Pb}$ & 0.753 \\
\hline
\end{tabular}

${ }^{a}$ Usually there are 37 data pairs, for which $\left|r_{\text {crii }}\right|=0.325$ at $95 \%$ probability of being real, 0.418 at $99 \%$ probability of being real.

${ }^{\mathrm{b}}$ Heated nephelometer inlet. Cell temperature is $\sim 15^{\circ} \mathrm{C}$ above ambient.

${ }^{c} \mathrm{NO}_{x}$ measurement includes $\mathrm{NO}, \mathrm{NO}_{2}$ and PAN. Laurel NO data are questionable; see text.

${ }^{\triangleleft}$ Average $r$ for $\mathrm{Al}, \mathrm{Si}, \mathrm{K}, \mathrm{Ca}, \mathrm{Fe}$.

transport. (3) The large broad features are not so common in the case of $\mathrm{NO}_{x}$ and consequently the importance of the spikes is emphasized. (4) Even the major broad features at one site are often absent at the other. These features all suggest that the closer point sources are more emphasized in the case of $\mathrm{NO}_{x}$ than in the case of $\mathrm{SO}_{2}$, perhaps connoting less efficient transport of $\mathrm{NO}_{x}$ than of $\mathrm{SO}_{2}$.
Among the candidate marker elements, the intersite correlation for $\mathrm{EC}$ was 0.83 (0.91 in the daytime), and $\sim 0.9$ for most of the others. The high correlation for $\mathrm{V}$ demonstrates that the failure to find significant intra-site correlations involving $\mathrm{V}$ did not stem from problems with the $\mathrm{V}$ data quality. The inter-site correlation for $\mathrm{Se}$ lies between those for $\mathrm{SO}_{2}$ and $\mathrm{SO}_{4}^{2-}$. The significantly lower inter-site correlation for $\mathrm{Pb}$ (and for $\mathrm{Br}$, though $\mathrm{Br}$ is less straightforward since it can be volatilized) implies that $\mathrm{Pb}$ may not be a reliable regional tracer of automotive emissions in this study because of analytical errors or local emissions.

In general the inter-site correlations are as strong at night as in the daytime (e.g. $b_{\text {scat }}$ inter-site $r=0.99$ on night-time runs). This suggests that meteorological coupling between the two sites was as good at night as in the daytime - that is, that the collapse of the daytime mixing layer and the formation of the nighttime inversion did not isolate the sites from each other.

\section{$\mathrm{SO}_{2}$ oxidation and deposition between the sites}

There was a $b_{\text {scat }}$ peak $\left(2.74 \times 10^{-4} \mathrm{~m}^{-1}\right)$ at Laurel at 1016 on 22 August (Fig. 7), with surface wind from $225^{\circ} \mathrm{T}$ at $13.6 \mathrm{~m} \mathrm{~s}^{-1}$. At 1104 this peak (now 3.30 $\times 10^{-4} \mathrm{~m}^{-1}$ ) reached Allegheny, at which time the surface wind was from $294^{\circ} \mathrm{T}$ at $8.3 \mathrm{~m} \mathrm{~s}^{-1}$ at Allegheny (and $222^{\circ} \mathrm{T}$ at $6.8 \mathrm{~m} \mathrm{~s}^{-1}$ at Laurel). The increase in peak height measured from the continuum (Fig. 7) was actually $(0.59 \pm 0.18) \times 10^{-4} \mathrm{~m}^{-1}$. The $35.5 \mathrm{~km}$ covered in $48 \mathrm{~min}$ corresponds to a transport speed of $12 \mathrm{~m} \mathrm{~s}^{-1}$. The peak had a half-width of $116 \mathrm{~min}$ at Laurel and $120 \mathrm{~min}$ at Allegheny, which at the transport speed just given corresponds to a spatial halfwidth of $90 \mathrm{~km}$. If we assume $b_{\text {seat }} / \mathrm{SO}_{4}^{2}$ $=849 \mathrm{~m}^{2} \mathrm{~mole}^{-1}$ (the regression coefficient in the caption in Fig. 6 corresponds to $849 \pm 32 \mathrm{~m}^{2}$ mole $^{-1}$ ), then the $0.59 \times 10^{-4} \mathrm{~m}^{-1}$ increase in $b_{\text {scat }}$ in transit from Laurel to Allegheny corresponds to a $\mathrm{SO}_{4}^{2-}$ increment of $69 \pm 21$ nanomoles $\mathrm{m}^{-3}$. The $\mathrm{SO}_{2}$ accompanying the $b_{\text {scat }}$ peak was $45.1 \pm 2$ ppb (1751 nanomoles $\mathrm{m}^{-3}$ ) at Laurel and $42.5 \pm 2 \mathrm{ppb}$ at Allegheny, i.e. no detectable change $\left(\Delta \mathrm{SO}_{2}=101 \pm 110\right.$ nanomoles $\left.\mathrm{m}^{-3}\right)$. The fact that the change in the sum of $\mathrm{SO}_{2}$ and (inferred) $\mathrm{SO}_{4}^{2-}$ was only a few per cent means that dispersion was not governing. These data imply a daytime rate coefficient of $0.049 \pm 0.015 \mathrm{~h}^{-1}$ for $\mathrm{SO}_{2}$ oxidation (higher, if $\mathrm{SO}_{2}$ deposition is nonzero) and $\leqslant 0.1 \mathrm{~h}^{-1}$ for $\mathrm{SO}_{2}$ dry deposition. (In the same $b_{\text {scat }}$ peak, the sum of $\mathrm{NO}+\mathrm{NO}_{2}+$ PAN declined from $19.2 \mathrm{ppb}$ at Laurel to $13.3 \mathrm{ppb}$ at Allegheny, for a rate coefficient of $\sim 0.5 \mathrm{~h}^{-1}$ for disappearance of (NO $\left.+\mathrm{NO}_{2}+\mathrm{PAN}\right)$ via deposition and chemical reaction).

\section{Particle size distributions}

The particle size distributions (Figs 8,9) of $\mathrm{H}^{+}$, $\mathrm{NH}_{4}^{+}$and $\mathrm{SO}_{4}^{2-}$ are all alike, with mass median aerodynamic diameters $0.72,0.79$ and $0.73 \mu \mathrm{m}$, respectively. Figure 8 shows a roughly log-normal dis- 


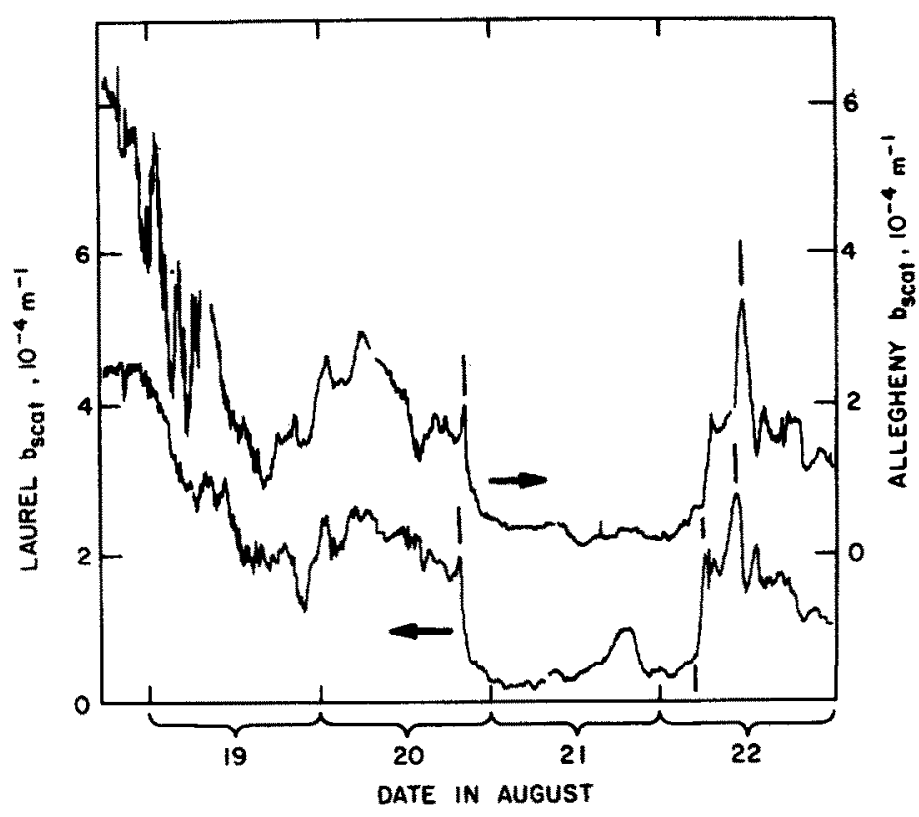

Fig. 7. Aerosol $b_{\text {seat }}$ at Allegheny Mountain and Laurel Hill (heated-inlet nephelometers), 19-22 August 1983. To separate the curves, the Allegheny ordinate is offset upwards.

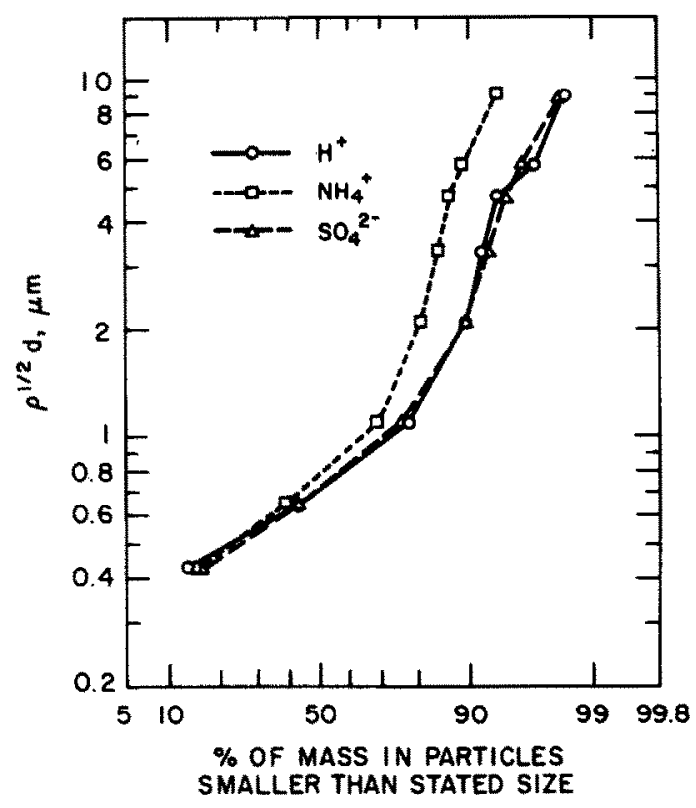

Fig. 8. Log probability plot of particle $\mathrm{H}^{+}, \mathrm{NH}_{4}^{+}$and $\mathrm{SO}_{4}^{2-}$ size distributions at the tower on Allegheny Mountain, 12-17, 19-22, 23-27 and 28 August 1983 $\left(480 \mathrm{~m}^{3}\right.$ sampled in 17,055 minutes). No rain.

tribution in the accumulation size mode, with MMED $\sim 0.67 \mu \mathrm{m}$ and $\sigma_{\mathrm{g}} \sim 1.6$ for all three species. The five impactor collections spanning the study gave similar distributions, with $\mathrm{MMED} 0.62-0.9 \mu \mathrm{m}$ for $\mathrm{H}^{+}$, $0.64-0.84$ for $\mathrm{NH}_{4}^{+}$and $0.59-0.86$ for $\mathrm{SO}_{4}^{2-}$. Most of the $\mathrm{H}^{+}$and $\mathrm{SO}_{4}^{2-}$ was on the two stages corresponding to the size range $0.43-1.1 \mu \mathrm{m}$.

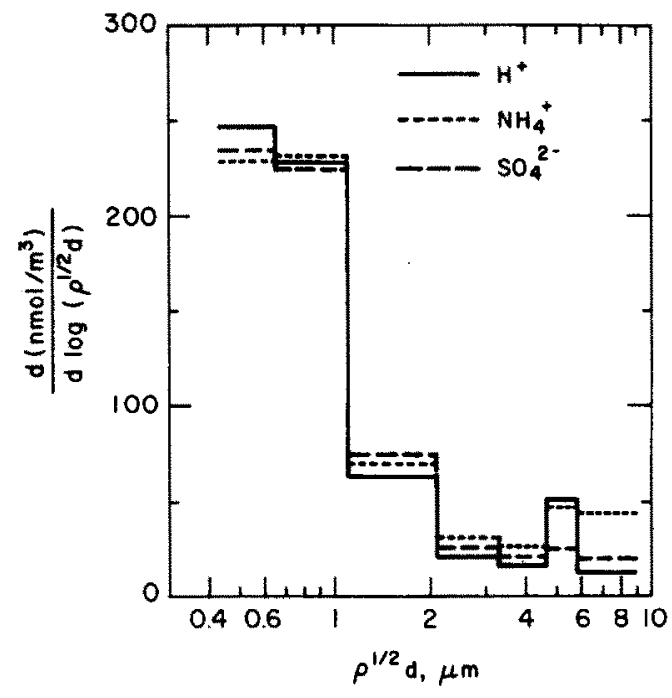

Fig. 9. Differential size distributions of particle $\mathrm{H}^{+}$, $\mathrm{NH}_{4}^{+}$and $\mathrm{SO}_{4}^{2-}$, same sample as in Fig. 8.

In the limited impactor data obtained in rain-only periods, the $\mathrm{SO}_{4}^{2-}$ maximum shifted upwards in size from the $0.43-1.1 \mu \mathrm{m}$ collection stages to the 0.65-2.1 $\mu \mathrm{m}$ collection stages and the MMED increased from $\sim 0.7 \mu \mathrm{m}$ to $\sim 0.9 \mu \mathrm{m}$.

The impactor $\mathrm{H}^{+} / \mathrm{SO}_{4}^{2-}$ ratio was highest between 0.43 and $1.1 \mu \mathrm{m}$, which is where $\mathrm{H}^{+}$and $\mathrm{SO}_{4}^{2-}$ were highest also.

Figure 8 shows 90,82 and $90 \%$ of the $\mathrm{H}^{+}, \mathrm{NH}_{4}^{+}$and $\mathrm{SO}_{4}^{2-}$, respectively, in particles $<2.5 \mu \mathrm{m}$, the nominal dividing line between coarse and fine fractions in the dichotomous sampler. XRF total aerosol S analysis of 
dichotomous sampler filters for the same period (it is evident in Table 2 that total aerosol $S$ is a close approximation to $\mathrm{SO}_{4}^{2-}$ ) gave a time-weighted average of $93 \%$ fine. The time-weighted average total aerosol $\mathrm{S}$ over the whole study including both sites was $90 \%$ fine (range $31 \%-100 \%$ ). The daytime average was $95.5 \%$ and the night-time average was $87 \%$, the difference resulting largely from a relatively few high-humidity runs with extraordinarily low per cent fine (Keeler et al., 1988).

The sum-of-stages $\mathrm{H}^{+}, \mathrm{NH}_{4}^{+}$, and $\mathrm{SO}_{4}^{2-}$ for all impactor data combined were 153.6, 177.5, and 162.8 nanomoles $\mathrm{m}^{-3}$, respectively, for an overall $\mathrm{H}^{+} / \mathrm{SO}_{4}^{2-}$ ratio of 0.94 , consistent with the filter data, and an ion balance $\left(\mathrm{H}^{+}+\mathrm{NH}_{4}^{+}\right) / \mathrm{SO}_{4}^{2-}-1.02$. The $\mathrm{H}^{+}$and $\mathrm{SO}_{4}^{2-}$ concentrations are $\sim 82 \%$ of the Allegheny best-estimate values (Table 2), suggesting sample recoveries of that magnitude from the impactors.

The observed MMED values for $\mathrm{H}^{+}$and $\mathrm{SO}_{4}^{2-}$ are near that for maximum light scattering per unit mass, consistent with the strong relationship observed between these species and $b_{\text {scat }}$. The MMED values are also within the respirable range, and this may be of some significance since respiratory responses to $\mathrm{H}_{2} \mathrm{SO}_{4}$ aerosols are reported at 1-h concentrations as low as $100 \mu \mathrm{g} \mathrm{m}^{-3}$, only twice the maximum runaverage $\mathrm{SO}_{4}^{2-}$ level encountered in the present study (see Lioy and Lippmann, 1986). With regard to acid deposition, for these particle sizes both wet removal and dry removal are relatively slow.

It was not possible to extract useful information on Se from the impactor samples. The dichotomous sampler filters showed that $\sim 87 \%$ of the Se (vs $90 \%$ of the aerosol S) was in the fine $(<2.5 \mu \mathrm{m})$ particle mode.

The size distributions shown here are consistent with the Shenandoah Valley measurements (Weiss et al., 1982) showing some $58 \%$ of the $\mathrm{NH}_{4}^{+}$and $\mathrm{SO}_{4}^{2-}$ in particles $<1 \mu \mathrm{m}$. They are also consistent with $\mathrm{H}^{+}$, $\mathrm{NH}_{4}^{+}$and $\mathrm{SO}_{4}^{2-}$ size distributions in the 1977 Allegheny study (Pierson et al., 1980).

\section{Relationships between concentrations and wind direc-} tion

It will be helpful in this discussion to consider Figs 2,10 and 11 together, using the run-number designations to identify the interrelationships of concentrations, times, air-mass movements and local wind directions. Figure 10 shows mixed-layer trajectories associated with the highest and lowest concentrations of species of major interest, i.e. $\mathrm{HNO}_{3}(\mathrm{~g})$, $\mathrm{SO}_{2}(\mathrm{~g})$ and aerosol $\mathrm{H}^{+}$and $\mathrm{SO}_{4}^{2-}$. Here we show total inorganic nitrate ( $\equiv \mathrm{HNO}_{3}(\mathrm{~g})$ plus fine aerosol $\mathrm{NO}_{3}^{-}$) instead of $\mathrm{HNO}_{3}(\mathrm{~g})$ alone since the former avoids the issue of $\mathrm{NH}_{4} \mathrm{NO}_{3}$ association/dissociation; the difference between $\mathrm{HNO}_{3}(\mathrm{~g})$ and total inorganic $\mathrm{NO}_{3}^{-}$is small $(\sim 10 \%)$. One must recognize that the mixedlayer trajectories are calculated by averaging the winds from the surface to the top of the mixing layer (Heffter, 1980; Samson, 1980) and should be viewed conceptually rather than in a literal sense. Figure 10 shows concentrations plotted against measured surface wind direction at the towers. The wind direction for each run is the vector resultant of the continuously varying wind vectors during the run. There often was considerable difference between surface wind direction-either estimated by the NWS or measured at the towers-and mixed-layer-trajectory wind direction. For example, from the evening of 12 August to the evening of 15 August (runs 13-19), with 72-h mixedlayer trajectories persistently from $035 \pm 005^{\circ} \mathrm{T}$ (Fig. 10), the winds measured at the towers came from $120 \pm 45^{\circ} \mathrm{T}$. (Of course there were also many periods when the directions were the same, and there is no reason that the surface and mixed-layer wind directions should be identical.)

In the set of four species dealt with here $-\mathrm{HNO}_{3}$, $\mathrm{SO}_{2}$ and aerosol $\mathrm{H}^{+}$and $\mathrm{SO}_{4}^{2-}$ - the highest (or lowest) concentrations of one species tended to be associated with the same trajectories as the highest (or lowest) concentrations of the other three (Fig. 10). In fact the set for low $\mathrm{H}^{+}$is identical to the set for low $\mathrm{SO}_{4}^{2-}$. It is useful, however, to separate the trajectories into four categories: (I) high $\mathrm{H}^{+}, \mathrm{SO}_{4}^{2-}, \mathrm{HNO}_{3}, \mathrm{SO}_{2}$; (II) low $\mathrm{H}^{+}$and $\mathrm{SO}_{4}^{2-}$, low to high $\mathrm{HNO}_{3}$ and $\mathrm{SO}_{2}$ (two subcategories); (III) moderate to high $\mathrm{H}^{+}$and $\mathrm{SO}_{4}^{2-}$, low to moderate $\mathrm{HNO}_{3}$, low $\mathrm{SO}_{2}$; (IV) low $\mathrm{H}^{+}, \mathrm{SO}_{4}^{2-}, \mathrm{HNO}_{3}, \mathrm{SO}_{2}$.

(I) $\mathrm{High} \mathrm{H}^{+}, \mathrm{SO}_{4}^{2-}, \mathrm{HNO}_{3}, \mathrm{SO}_{2}$. These were associated with trajectories and local winds from the west (Figs 10,11). The local west winds with high $\mathrm{SO}_{4}^{2-}$ also tended to have speeds slightly above average, so that in terms of advection flux (moles $\mathrm{m}^{-2} \mathrm{~s}^{-1}$ ) the westerly preference was even stronger. This is consonant with the fact that the two sites lie $\sim 150 \mathrm{~km}$ east of the highest density of $\mathrm{SO}_{2}$ emissions in the U.S. (Barrie et al., 1984; Clark, 1980). Mixed-layer transport times from this source region to the sites would have been on the order of $12 \mathrm{~h}$.

High $\mathrm{H}^{+}, \mathrm{SO}_{4}^{2-}, \mathrm{HNO}_{3}$ and $\mathrm{SO}_{2}$ were also the aftermath of severe local stagnation. The day of 16 August (run 20), in the middle of the ascent toward high $\mathrm{H}^{+}, \mathrm{SO}_{4}^{2-}, \mathrm{HNO}_{3}$ and $\mathrm{SO}_{2}$ (and also PAN, $\mathrm{NO}_{x}, \mathrm{O}_{3}, \mathrm{EC}$ ), coincided with essentially zero wind at the Allegheny tower $\left(0.3 \mathrm{~m} \mathrm{~s}^{-1}\right.$ vector, 0.8 scalar $)$ and an ill-defined tower wind direction (indeed, opposite of that at Laurel). Mixed-layer trajectories ending at Allegheny or Laurel during this local stagnation period had started $72 \mathrm{~h}$ earlier in the vicinity of the sites, gone west to the Ohio River, and doubled back. By far the highest run-average NO in the study occurred at Allegheny on this run (1.96 ppb, $\mathrm{NO} / \mathrm{NO}_{2}$ mole ratio 0.24$)$, much of it contained in a 13-min 31ppb spike with $\mathrm{NO} / \mathrm{NO}_{2} \sim 1.0$ occurring at 0912 along with high $\mathrm{CNC}, \mathrm{O}_{3}$ suppression and wind from $090^{\circ} \mathrm{T}$, signifying a sudden influx of Turnpike traffic pollutants (probably accumulated during the preceding night when most of the traffic was diesel trucks, as the run-average $\mathrm{Pb}$ was low and the $\mathrm{NO}_{x} / \mathrm{Pb}$ ratio, 3050 moles (g-atom) ${ }^{-1}$, was $\sim 4$ times too high for a 

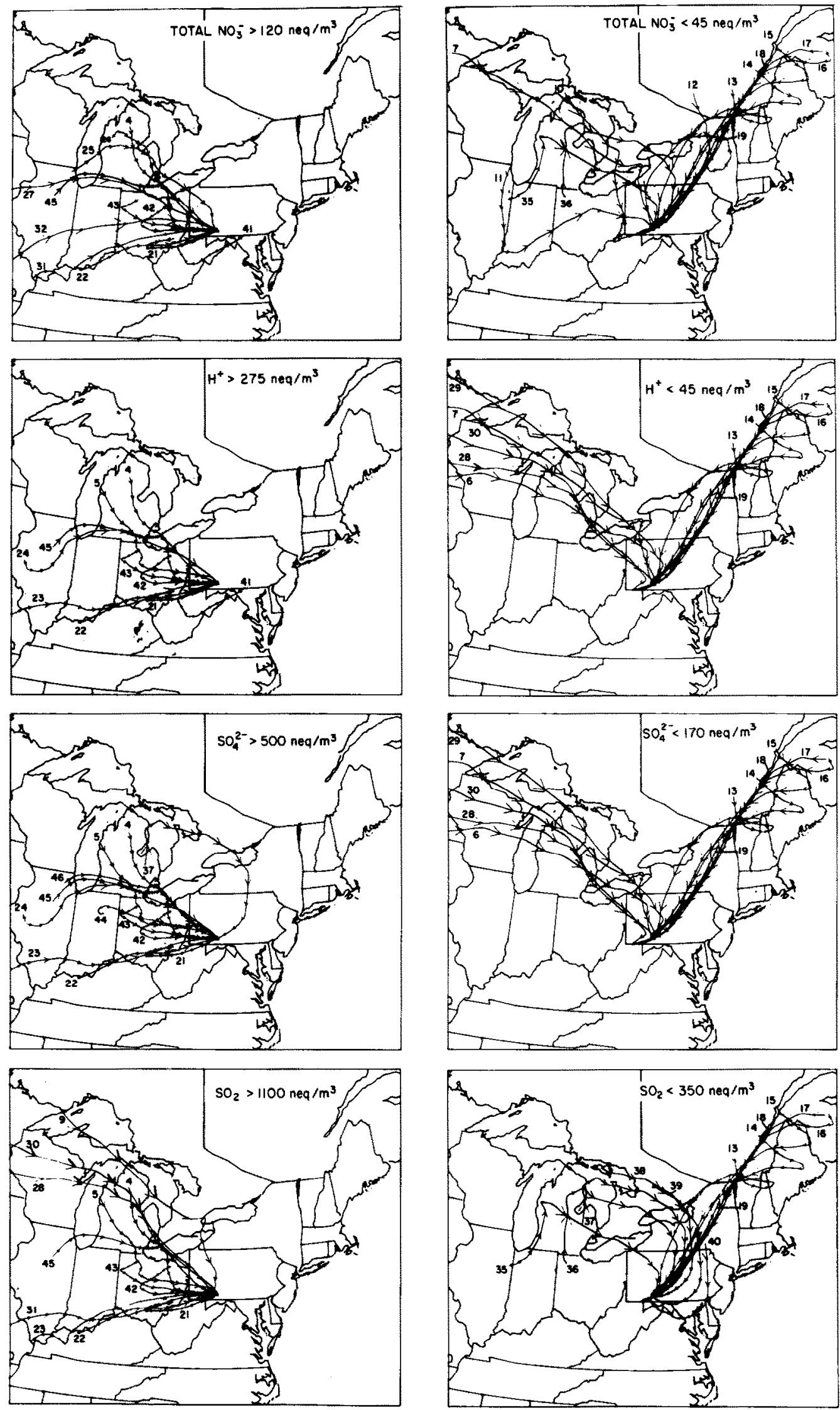

Fig. 10. Mixed-layer trajectories associated with (arriving at 0200 or 1400 EDT during) sampling runs with highest and lowest run-average concentrations of the indicated species at Allegheny Mountain, August 1983. The Laurel Hill data were similar. The high and low cutoffs were chosen to include about a quarter of the trajectories in each frame. Arrowheads every $6 \mathrm{~h}$ signify wind speed. The run number applicable to each trajectory, with designations as in Fig. 2, is shown. Total $\mathrm{NO}_{3}^{-}=\mathrm{HNO}_{3}(\mathrm{~g})+$ fine-particle $\mathrm{NO}_{3}^{-}$. 

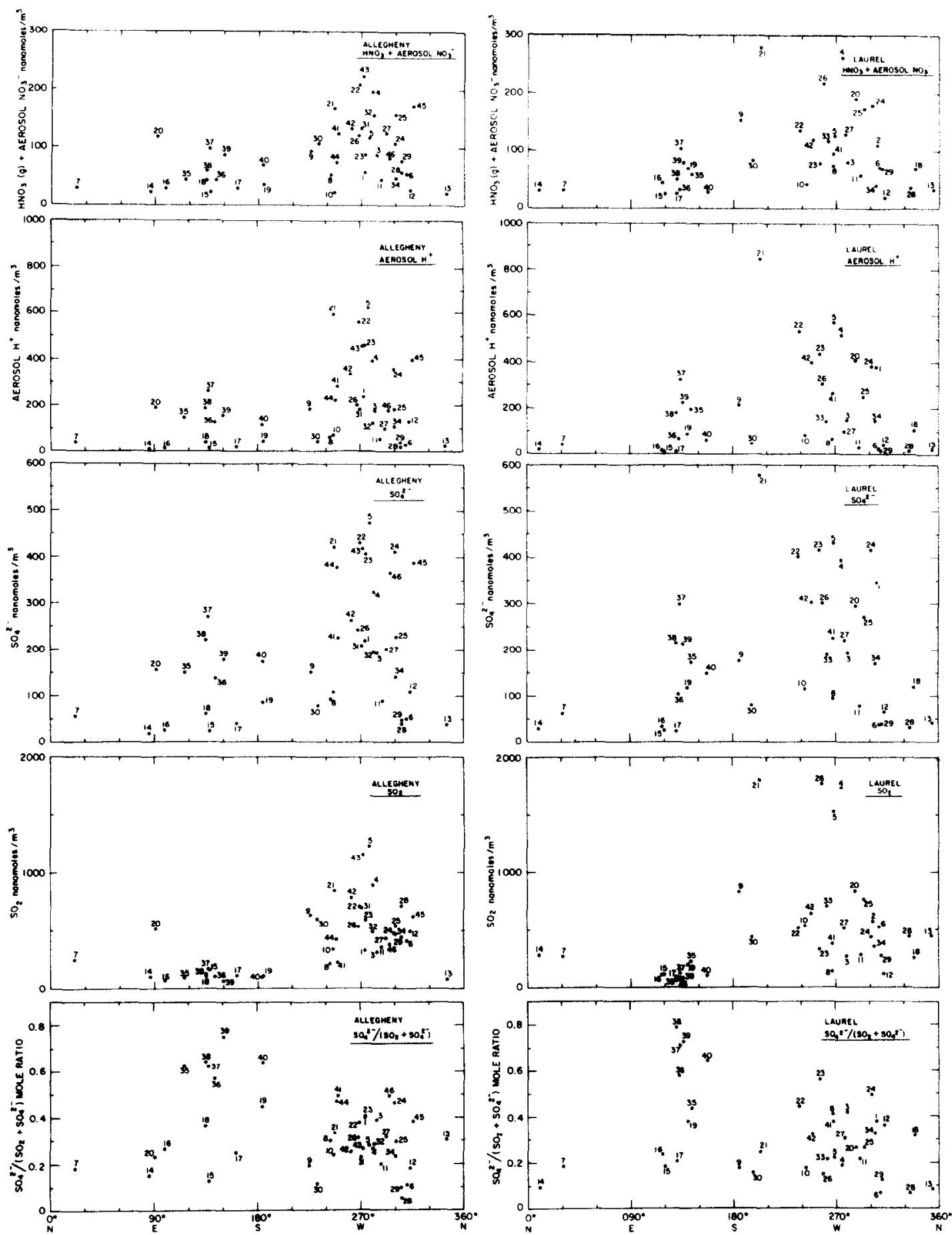

Fig. 11. Run-average concentrations vs local surface wind direction (direction the wind is from) at the Allegheny Mountain and Laurel Hill towers, August 1983. Wind direction for each run is the vector resultant of all wind speeds and directions during the run. Run number designations are as in Fig. 2. Runs 13 through 19 were associated with trajectories from NNE ("Whiteface trajectories"). The trajectories for runs 35-40 were associated with a high pressure system. Run 20 at Allegheny corresponds to an extremely low wind speed $\left(0.3 \mathrm{~m} \mathrm{~s}^{-1}\right)$ at the tower.

traffic signature). During this day there was a considerable $b_{\text {ecat }}$ increase.

The effect of this stagnation manifested itself on the night of 16 August (run 21)-especially at Laurel (see Figs 2 and 11), where maximum run averages for the study were registered for $\mathrm{HNO}_{3}$ (and total $\mathrm{NO}_{3}^{-}$), $\mathrm{SO}_{2}$ and aerosol $\mathrm{H}^{+}, \mathrm{SO}_{4}^{2-}$ and EC. Near-maximum values of all of these quantities were registered at Allegheny. The $\mathrm{H}^{+} / \mathrm{SO}_{4}^{2-}$ ratio was at its maximum at both sites (mole ratio 1.46 at Laurel). Aerosol mass 
and Se were high at both sites. Run-average $b_{\text {scat }}$ was high, PAN near maximum and $\mathrm{O}_{3}$ the highest of the study. $\mathrm{NO}_{x}$ was maximum at Laurel but low at Allegheny. The $\mathrm{SO}_{4}^{2-} /\left(\mathrm{SO}_{2}+\mathrm{SO}_{4}^{2-}\right)$ ratio was ordinary or low. Surface wind (vector) was from $203.5^{\circ} \mathrm{T}$ at $1.1 \mathrm{~ms}^{-1}$ at Laurel, $247^{\circ} \mathrm{T}$ at $2.15 \mathrm{~ms}^{-1}$ at Allegheny, as measured at the towers. NWS surface trajectories ending at Laurel on this night $\left(\sim 205^{\circ} \mathrm{T}\right.$ at $\left.0.6 \mathrm{~ms}^{-1}\right)$ were roughly consistent with the tower measurements, and similarly at Allegheny. The arriving mixed-layer air, meanwhile, had been near the sites $72 \mathrm{~h}$ earlier, moved west to the Ohio River area, and doubled back (see Fig. 10). These observations suggest localized behavior in response to local stagnation, i.e. that local wind direction and speed were important. This was the beginning of the main acid episode of the study.

In succeeding days as the stagnation ended and persistent westerly winds again set in (runs 22-24, Fig. 10), the $\mathrm{HNO}_{3}$ and $\mathrm{SO}_{2}$ declined quickly but $\mathrm{SO}_{4}^{2-}$ took several days to clear out.

The prospect that aerosol $\mathrm{H}^{+}$and $\mathrm{SO}_{4}^{2-}$ might exhibit localized behavior along with the $\mathrm{SO}_{2}$ was not anticipated. The closest strong $\mathrm{SO}_{2}$ sources in a southerly direction are $\sim 100 \mathrm{~km}$ from Laurel (Fig. 1) which, at the surface wind speed recorded, translates to a transport time of $\sim 25 \mathrm{~h}$. The high levels of EC and other pollutants presumably are a consequence of a general build-up under the stagnant conditions.

(II) Low $\mathrm{H}^{+}$and $\mathrm{SO}_{4}^{2-}$, low to high $\mathrm{HNO}_{3}$ and $\mathrm{SO}_{2}$. These were associated with fast-moving trajectories out of the west (e.g. runs 11, 31; see Figs 10, 11). Even though they passed right through the source region, these trajectories did not deliver high $\mathrm{H}^{+}$or $\mathrm{SO}_{4}^{2-}$ and the $\mathrm{SO}_{2} \rightarrow \mathrm{SO}_{4}^{2-}$ conversion was low. Wind speed evidently differentiates this category from the preceding one; inspection of westerly trajectories associated with high $\mathrm{H}^{+}, \mathrm{SO}_{4}^{2-}, \mathrm{HNO}_{3}$ and $\mathrm{SO}_{2}$ reveals a good deal of meandering and stagnation in some of them in areas to the west.

Low $\mathrm{H}^{+}$and $\mathrm{SO}_{4}^{2-}$, low to medium $\mathrm{HNO}_{3}$ and low to high $\mathrm{SO}_{2}$ were associated also with fast-moving trajectories out of the northwest (runs 6, 7, 28-30, Figs 2,10,11), similar to the trajectories in the 1977 study that brought low $\mathrm{H}^{+}$and $\mathrm{SO}_{4}^{2-}$ but no particular pattern of $\mathrm{SO}_{2}$ (Pierson et al., 1980; Samson, 1980). The variability of $\mathrm{SO}_{2}$ probably has to do with the power plants nearby to the northwest (Fig. 1) and the chance of impact from their plumes. Run 29 (daytime 21 August) was especially low in all species - not only the four under discussion here, but all species including trace elements; the associated trajectory was a fastmoving trajectory from the northwest which apparently missed all of the large cities and industrial centers lying in that direction; it had especially high $\mathrm{SO}_{2} / \mathrm{Se}$ ratio and especially low $\mathrm{SO}_{4}^{2-} / \mathrm{Se}$ ratio, indicating that most of the $\mathrm{SO}_{2}$ was picked up only shortly before arrival.

(III) Moderate to high $\mathrm{H}^{+}$and $\mathrm{SO}_{4}^{2-}$, low to moderate $\mathrm{HNO}_{3}$, and low $\mathrm{SO}_{2}$. These were associated with air arriving from the southeast after having travelled in a long clockwise loop out of the midwest and around through the north and northeast (runs 35-40). This pattern set in on the morning of 23 August and continued through the night of 25 August. The sites during this interval were on the back side of a high pressure center located to the north and proceeding in a southeasterly direction. The arriving air had been in transit from the Midwest (say, Ohio and Indiana) for $\geqslant 72 \mathrm{~h}$ and $>1000 \mathrm{~km}$.

This low- $\mathrm{SO}_{2}$ air upon arrival contained low $\mathrm{O}_{3}$, ordinary levels of $\mathrm{HNO}_{3}$, and greatly elevated $\mathrm{H}^{+}$and $\mathrm{SO}_{4}^{2-}$ by comparison with other occasions when local winds were from the southeast (see Fig. 11). PAN and $\mathrm{NO}_{x}$ levels were ordinary. This air had the highest $\mathrm{SO}_{2} \rightarrow \mathrm{SO}_{4}^{2-}$ conversions ever encountered in this study; some $65 \%$ of the $\mathrm{SO}_{2}+\mathrm{SO}_{4}^{2-}$ during the 3 days existed as $\mathrm{SO}_{4}^{2-}$ (Fig. 11). All of this is consistent with above-average aging time and concomitant $\mathrm{SO}_{2}$ oxidation/removal.

Maximum $\mathrm{SO}_{4}^{2-} / \mathrm{Se}$ ratios $\left(\geqslant 20,000 \mathrm{gg}^{-1}\right)$ were observed during this same period (actually, runs 35-39). Se supposedly traces both $\mathrm{SO}_{2}$ and $\mathrm{SO}_{4}^{2-}$; enhancement of the $\mathrm{SO}_{4}^{2-} / \mathrm{Se}$ ratio (vs the study average, which was 8400 at Allegheny, 7800 at Laurel, 5300 in 1977 at Allegheny) cannot be achieved by $\mathrm{SO}_{2}$ deposition but can be achieved by $\mathrm{SO}_{2}$ oxidation or by Se deposition. Se deposition velocities at Allegheny, at least at night, were $<0.1 \mathrm{~cm} \mathrm{~s}^{-1}$ (Pierson et al., 1986), consistent with their small particle size (87\% of the mass $<2.5 \mu \mathrm{m}$ ). Thus Se deposition can probably be discounted to a first approximation and the enhanced $\mathrm{SO}_{4}^{2-} / \mathrm{Se}$ ratios probably have to be explained by $\mathrm{SO}_{2} \rightarrow \mathrm{SO}_{4}^{2-}$ conversion during transport from the source area around the high pressure center to the sites, at rates of the order of $1 \% \mathrm{~h}^{-1}$. (In order that $\sim 65 \%$ of the $\mathrm{SO}_{2}+\mathrm{SO}_{4}^{2-}$ exist as $\mathrm{SO}_{4}^{2-}$ during these runs as stated in the preceding paragraph, in the absence of $\mathrm{SO}_{2}$ deposition during a 3-day journey from the $\mathrm{SO}_{2}$ source region, the conversion rate would have to be $\sim 0.015 \mathrm{~h}^{-1}$.)

The long transport times involved in these trajectories, together with the high daytime $\mathrm{HNO}_{3}(\mathrm{~g})$ deposition velocity, probably explain the fact that the $\mathrm{HNO}_{3}(\mathrm{~g})$ concentrations were not particularly high in this category.

(IV) Low $\mathrm{H}^{+}, \mathrm{SO}_{4}^{2-}, \mathrm{HNO}_{3}, \mathrm{SO}_{2}$. These were associated with the Whiteface trajectories - that is, trajectories out of the NNE (runs 13-19) over the 3day period from the night of 12-13 August and into the evening of 15 August. For much of this time the trajectories to Allegheny/Laurel passed directly over the ASRC (SUNY-Albany) site on Whiteface Mountain (NY). Extremely low $\mathrm{SO}_{4}^{2-}$ levels were measured during this period also at Whiteface and at Underhill, Vermont (Husain et al., 1984; Poirot and Wishinski, 1986).

In summary, we have identified three meteorological regimes for high acidity: (1) stagnation over upwind source regions lying to the west, followed by slow advection from the source region, with high $\mathrm{HNO}_{3}$, 
$\mathrm{SO}_{2}$ and aerosol $\mathrm{H}^{+}$and $\mathrm{SO}_{4}^{2 \cdots}$; (2) local stagnation, with high concentrations of the same species; and (3) regional transport around to the back side of a high pressure system, with elevated aerosol $\mathrm{H}^{+}$and $\mathrm{SO}_{4}^{2-}$, modest $\mathrm{HNO}_{3}$ and depletion in $\mathrm{SO}_{2}$. Low acidity occurs with air masses from northerly sectors.

$V$ concentrations at Laurel were highest when the tower winds were from the sector $131^{\circ} \leqslant \theta \leqslant 157^{\circ} \mathrm{T}$ (runs 37-40). V concentrations at Allegheny were highest in the same runs, where now the sector limits are $135^{\circ} \leqslant \theta \leqslant 184^{\circ}$, similar to the 1977 Allegheny situation in which an order-of-magnitude increase in $V$ was encountered with tower winds from $160^{\circ} \mathrm{T}$. The series of looping trajectories associated with the back side of the high pressure system (runs 35 40) began with low $V$ concentrations (runs 35,36 ) and then, as the loops reached progressively farther into the East, the $\mathrm{V}$ concentrations delivered at Allegheny rapidly increased (runs 37-40). Though advection from the Northeast might appear to explain the high $\mathrm{V}$, the $\mathrm{SO}_{4}^{2-} / \mathrm{V}$ mass ratios even at the highest $\mathrm{V}$ concentrations (runs 38-40) were an order of magnitude higher than East Coast nonurban ratios given by Altshuller (1976); and advection of extraordinarily high $\mathrm{V}$ from $160^{\circ}$ in the 1977 Allegheny study was not preceded by traverses of the Northeast. A local V source to the SSE (say, in Cumberland, MD), on the other hand, is inconsistent with the lack of high $\mathrm{V}$ in runs 35 and 36. We have to leave the very interesting (for example, see Rahn and Lowenthal, 1985) $\mathrm{V}$ behavior once again unresolved.

Further regarding the $\mathrm{NO}_{x} / \mathrm{Pb}$ ratios, the $\mathrm{Pb}$ runaverage concentrations at Allegheny have their maximum at tower winds from $270^{\circ}$ like the other species in Fig. 11, whereas $\mathrm{NO}_{x}$ has two maxima and they are at $130^{\circ}$ and $300^{\circ} . \mathrm{NO}_{x}$ thus seems to be more subject than is $\mathrm{Pb}$ to the influence of local traffic, probably in part because most of the traffic $\mathrm{Pb}$ is emitted from spark-ignition vehicles which predominate during the daytime when the atmospheric dispersion/dilution of local emissions is greater. Night-time traffic emissions are dominated by heavy-duty diesels, with high $\mathrm{NO}_{x}$ (Gorse, 1984) and low Pb (Pierson and Brachaczek, 1983).

Relationships between concentrations and wind speed history

We have mentioned in the preceding section the enhancing effect of local stagnation on concentrations, as well as the enhancing effect of slow-moving meandering trajectories and upwind stagnation compared to fast-moving trajectories from the same direction. This upwind stagnation/transport time effect can be quantified as was done by Samson (1980). Samson found that the $\mathrm{SO}_{4}^{2-}$ concentration at a number of Northeast sites (including 1977 Allegheny) was correlated with the inverse of the mixed-layer wind speed $\geqslant 24 \mathrm{~h}$ upwind of the sampling point, and interpreted this to mean that maximum $\mathrm{SO}_{4}^{2-}$ concentrations accompanied upwind wind speeds low enough to permit $\mathrm{SO}_{2}$ accumulation over source areas and oxidation to $\mathrm{SO}_{4}^{2-}$ during transport. It is interesting that at High Point, $\mathrm{NJ}$, the time needed for the correlation to reach critical values was $\sim 48 \mathrm{~h}$, vs $\sim 36 \mathrm{~h}$ at Allegheny, in excellent agreement with the $\sim 12-\mathrm{h}$ downwind displacement of High Point from Allegheny.

The 1983 Allegheny/Laurel data demonstrated the existence of correlations not only for $\mathrm{SO}_{4}^{2-}$ but for aerosol $\mathrm{H}^{+}$as well and, to a lesser degree, for $\mathrm{HNO}_{3}(\mathrm{~g})$ and aerosol $\mathrm{NH}_{4}^{+}$(Fig. 12). This time they reached critical values at upstream offsets of $\sim 24 \mathrm{~h}$. $\mathrm{SO}_{2}$ (not illustrated) also showed correlations but they barely reached the critical line.

Atmospheric concentrations at Allegheny were higher in 1983 than in 1977 (e.g. $\mathrm{H}^{+}$average at Allegheny 193 nanomoles $\mathrm{m}^{-3}$ in 1983 vs 155 in 1977). Wind speed could have been a factor; the average scalar wind at the tower was over twice as high in 1977 as in the present study, and the mixed-layer average wind speed calculated from the mixed-layer trajectories was about 3 times as high in 1977 as in the present study. The implied dilution effect of wind speed history is confounded a bit by the fact that northerly trajectorics wcre more prevalent in the present study; these trajectories have high wind speeds and low $\mathrm{SO}_{4}^{2}$, however, so that removing them would only further amplify the $\mathrm{SO}_{4}^{2-}$ and wind speed differences between 1983 and 1977.

Relationship between concentrations and upwind precipitation

The occurrence of precipitation upwind of the sites, and the place of occurrence relative to the pollutant sources, may explain some of the difference between the 1977 and 1983 concentrations of $\mathrm{SO}_{2}$ and aerosol $\mathrm{H}^{+}$and $\mathrm{SO}_{4}^{2-}$. The major $\mathrm{SO}_{2}$ source regions west of Allegheny/Laurel are typically $<1$ day's transport distance away from the sites. The occurrence of rain several days upwind of the sites should have less effect on the concentrations at the sites than the occurrence

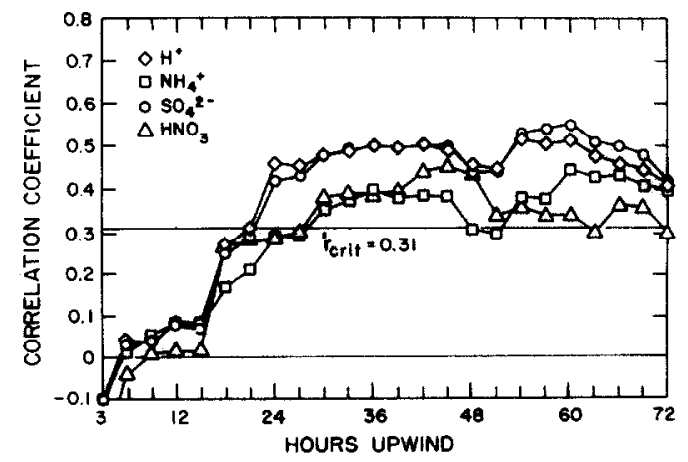

Fig. 12. Correlation coefficients, as a function of hours upstream, between the inverse of mixed-layer wind speed upstream and resultant concentrations at Allegheny Mountain, August 1983. The $r_{\text {crit }}$ line is for $p=0.05$. 
of rain between the sources and the sites. Upwind precipitation was more frequent in the 1977 experiment than in the present one, and this was especially true of rain between the source region and the sampling sites. These matters have been discussed (Pierson et al., 1987) in connection with the concentrations of acidic species in rain, which were much higher in 1983 than in 1977. The discussion applies equally to atmospheric concentrations: The differences can probably be rationalized in terms of upwind rain and upwind stagnation, their order of occurrence relative to each other and to passage through $\mathrm{SO}_{2}$ source regions, and average wind speed (dispersion/stagnation).

Regarding the 1983 data alone, rain occurred within $72 \mathrm{~h}$ upwind along about half of the trajectories, but it tended to occur along the ones advecting lower $\mathrm{SO}_{4}^{2-}$. In fact, the highest $15 \%$ of the aerosol $\mathrm{H}^{+}$and $\mathrm{SO}_{4}^{2-}$ concentrations were all associated with air masses which had encountered no rain within $72 \mathrm{~h}$. Cases of low $\mathrm{SO}_{4}^{2-}$ without prior rain were also recorded but the trajectories in these instances were from the northerly directions. The $\mathrm{HNO}_{3}$ dependence on 72 -h upwind precipitation was relatively weak, consistent with its shorter transport scale.

\section{Visual range}

Figure 13 shows that ambient $\mathrm{SO}_{4}^{2-}$ at Allegheny was a determinant or predictor of visual range $L_{v}$, just as it had been for $b_{\text {scat }}$. This holds for local $L_{\mathrm{v}}$ as well as for $L_{\mathrm{v}}$ at Altoona, as illustrated, and for Johnstown (for locations, refer to Fig. 1). An exception is seen at the lowest $\mathrm{SO}_{4}^{2-}$ concentrations, where $\mathrm{SO}_{4}^{2-}$ overpredicts $L_{\mathrm{v}}$ because, presumably, other substances such as EC (e.g. Japar et al., 1986) are now able to play a significant role in $L_{v}$ degradation. This coupling between high $\mathrm{SO}_{4}^{2-}$ and low $L_{v}$ links the issues of acidity and visual air quality in the Northeast, in that high $\mathrm{SO}_{4}^{2-}$ implies both poor visibility and high acidity.

The vertical scales of $\mathrm{SO}_{4}^{2-}$ and $L_{\mathrm{v}}^{-1}$ in Fig. 13 were matched in such a way as to get maximum overlap between $\mathrm{SO}_{4}^{2-}$ and $L_{\mathrm{v}}$. This normalization turns out to be

$$
L_{\mathrm{v}}(\mathrm{km}) \cdot \mathrm{SO}_{4}^{2-}\left(\text { nanomole } \mathrm{m}^{-3}\right)=1680
$$

or, in terms of $\mathrm{SO}_{4}^{2-}$ mass, $0.16 \mathrm{~g} \mathrm{~m}^{-2}$. The correlation coefficient was 0.77 between $\mathrm{SO}_{4}^{2-}$ and $L_{\mathrm{v}}^{-1}$ at Allegheny, 0.82 between $\mathrm{SO}_{4}^{2-}$ at Allegheny and $L_{\mathrm{v}}^{-1}$ at Altoona. There was no discernible relationship between $L_{v} \cdot \mathrm{SO}_{4}^{2-}$ and r.h.

If we multiply the clear-air instantaneous $b_{\text {scat }}$ by 1.2 (to correct for the nephelometer heating) and add 0.2 $\times 10^{-4} \mathrm{~m}^{-1}$ (Rayleigh scattering from the gas phase) to obtain $B_{\text {scat }}$, then the product $L_{\mathrm{v}} \cdot B_{\text {scat }}$ at Allegheny is $2.5 \pm 1.0$. The corresponding contrast threshold, $8.5 \%$, is poorer than the $2-5 \%$ considered realistic for a trained observer and ideal targets (neither of which we had), but the discrepancy corresponds to an underestimate of only $\sim 25 \%$ in visual range. Allegheny and NWS Altoona $L_{v}$ values were similar on the average. The correlation between $B_{\text {scat }}$ and $L_{v}^{-1}$ at Allegheny was high $(r=0.92)$.

The dominance of $\mathrm{SO}_{4}^{2-}$ in $L_{\mathrm{v}}$ is consistent not only with the dominance of $\mathrm{SO}_{4}^{2-}$ in $b_{\text {scat }}$ but also with the observation that scattering constituted $\sim 87 \%$ of the aerosol-caused light extinction on the average during this study (Japar et al., 1986). This $87 \%$ figure in turn is the same as has been reported in other studies of the Northeast aerosol (Ferman et al., 1981; Wolff et al., 1982).

As cxpected since the aerosol mass is composed largely of $\mathrm{SO}_{4}^{2-}$, aerosol mass was highly correlated to $L_{\mathrm{v}}^{-1}(r=0.73)$. Stevens et al. (1984) have found even better correlations of $L_{\mathrm{v}}^{-1}$ with $\mathrm{SO}_{4}^{2-}(r=0.89)$ and with aerosol mass $(r=0.95)$ than were found here.

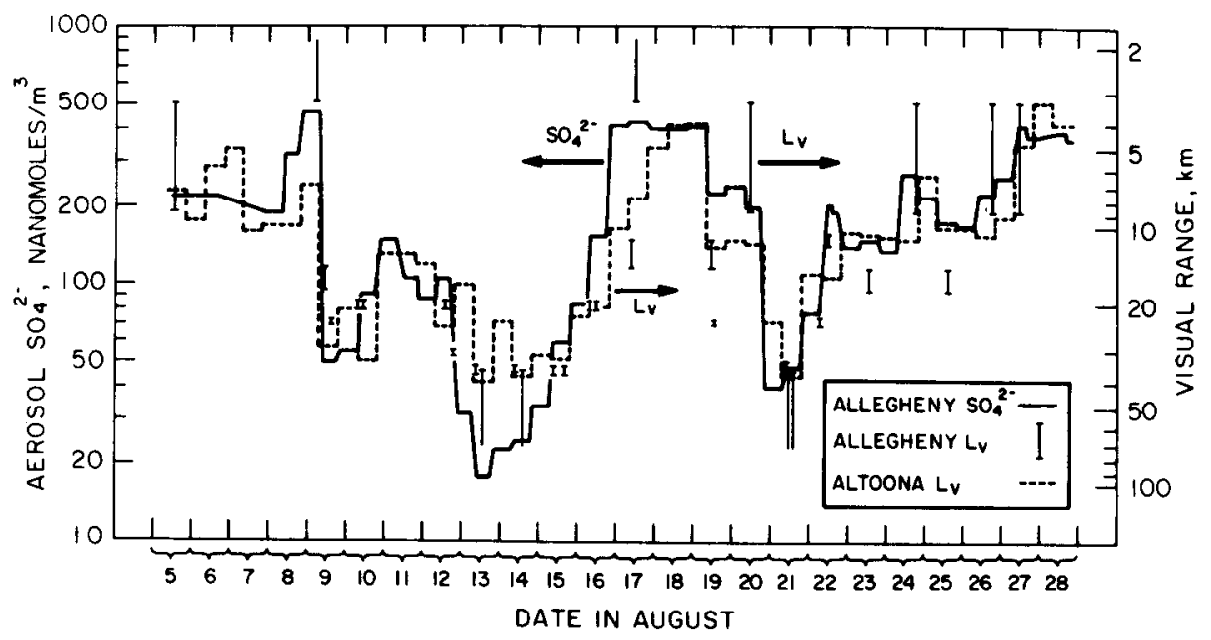

Fig. 13. Comparisons of ambient $\mathrm{SO}_{4}^{2-}$ and visual range $\left(L_{\mathrm{v}}\right)$, August 1983. Solid line: $\mathrm{SO}_{4}^{2-}$ concentrations on the tower on Allegheny Mountain. Bars: $L_{v}^{-1}$ at the Allegheny tower. Broken line: 12 $\mathrm{h}$ a verages of hourly visual ranges at the Altoona/Martinsburg NWS station. $L_{\mathrm{v}}$ sightings in cloud or fog are excluded. 
Regression of aerosol mass concentration against heated-nephelometer $b_{\text {scat }}$ gave mass scattering coefficients of $3.3 \pm 0.6 \mathrm{~m}^{2} \mathrm{~g}^{-1}(\bar{r}=0.75)$ for fine, and 3.2 $\pm 0.5 \mathrm{~m}^{2} \mathrm{~g}^{-1}(\bar{r}=0.8$, Table 4$)$ for coarse plus fine. Weiss et al. (1982) report $4.3 \mathrm{~m}^{2} \mathrm{~g}^{-1}$ for fine $(\leqslant 1 \mu \mathrm{m})$ dilution-dried particles in the Shenandoah Valley summertime $\mathrm{SO}_{4}^{2-}$ haze.

Oddly, the $\mathrm{SO}_{4}^{2-}$ episode that began about 16 August (Fig. 13) did not begin at the same time at Altoona, only $60 \mathrm{~km}$ away, or at Johnstown, only $40 \mathrm{~km}$ away. Pronounced $L_{\mathrm{v}}$ degradation lagged the Allegheny Mountain air-quality degradation by fully $24 \mathrm{~h}$ at Altoona (Fig. 13) and by nearly as much at Johnstown. The lag time is at least consistent with the surface wind speeds and directions recorded at Allegheny during that time.

\section{DISCUSSION}

The results of the study present a fairly coherent picture of summertime atmospheric acidity in the northeastern U.S. near the main precursor source region. The main species involved are $\mathrm{HNO}_{3}(\mathrm{~g})$, $\mathrm{SO}_{2}(\mathrm{~g})$ and aerosol $\mathrm{H}^{+}$associated with partially neutralized (by $\left.\mathrm{NH}_{3}\right) \mathrm{H}_{2} \mathrm{SO}_{4}$. The amount of $\mathrm{NH}_{3}(\mathrm{~g})$ is almost too small to matter. In terms of their respective $\mathrm{H}^{+}$equivalents or potential $\mathrm{H}^{+}$equivalents (2 per $\mathrm{SO}_{2}$ molecule, 1 per $\mathrm{HNO}_{3}$, etc.), the average atmospheric acidity contributions of the three components are

$\begin{array}{rrl}\mathrm{HNO}_{3}(\mathrm{~g}) & 78 \mathrm{neq} \mathrm{m}^{-3} & (7 \%) \\ \mathrm{SO}_{2}(\mathrm{~g}) & 900 \mathrm{neq} \mathrm{m}^{-3} & (75 \%) \\ \text { aerosol H } & 205 \mathrm{neq} \mathrm{m}^{-3} & (17 \%) \\ & \frac{2051 \mathrm{neq} \mathrm{m}^{-3}}{1181} & \text { Total }\end{array}$

at the two sites taken together. The apportionment is actually quite dependent on a number of factors such as the depletion of $\mathrm{SO}_{2}$ associated with longer travel times/distances, as we have seen.

Another 10 or $20 \%$ could be contributed by acids that were ignored such as $\mathrm{HCl}$, carboxylic acids, HONO and $\mathrm{N}_{2} \mathrm{O}_{5}$ (the $\mathrm{HNO}_{3}$ anhydride). $\mathrm{NO}_{2}$ and $\mathrm{PAN}$ are cxcluded on grounds stated in the Introduction, i.e. they did not contribute directly to acid deposition at the site. Their potential role as acid precursors, however, is significant (about 20\%, Table 2).

Most of the interest in acid deposition in the Northeast has centered upon receptor regions distant from sources and upon the long-range transport between source and receptor regions, almost as if the source regions themselves were not also receptors. Actually the deposition flux near the source obviously can be quite high and stream studies on Laurel Hill (DeWalle et al., 1985; Sharpe et al., 1984, 1987) have revealed considerable environmental damage evidently caused by acid deposition. The Allegheny and Laurel sites are in the area of highest rainfall $\mathrm{H}^{+}$ concentrations and highest annual totals of $\mathrm{H}^{+}$deposition in all of North America (Barrie and Hales, 1984; Hicks et al., 1984; Lynch et al., 1984, 1985; Olsen and Slavich, 1986; Sharpe et al., 1984).

The results described here resemble those in the acid sulfate 'white episodes' in Sweden (Brosset, 1978, 1980 ), but generalization to regions other than western Europe and the northeast U.S. is inappropriate. In remote areas, atmospheric acidity can be dominated by carboxylic acids (Keene and Galloway, 1984; Keene et al., 1983) which, together with $\mathrm{HNO}_{3}$, also figure prominently in the Los Angeles basin (Grosjean, 1988; Kawamura and Kaplan, 1987; Kawamura et al., 1985; Pierson and Brachaczek, 1988a, 1988b; Pierson et al., 1988).

Many of the results reported here had already been seen in the 1977 Allegheny Mountain experiment, such as the acidity and chemical composition of the aerosol, the trend of $\mathrm{H}^{+} / \mathrm{SO}_{4}^{2--}$ ratio with $\mathrm{SO}_{4}^{2-}$ concentration, the strong relationships among $b_{\text {scat }}$ and aerosol $\mathrm{H}^{+}$and $\mathrm{SO}_{4}^{2-}$, the relationship between $\mathrm{SO}_{4}^{2-}$ and $L_{\mathrm{v}}$, the aerosol $\mathrm{H}^{+}$and $\mathrm{SO}_{4}^{2-}$ size distributions, the time duration of the acid $\mathrm{SO}_{4}^{2-}$ episodes, the lack of relationship between $\mathrm{SO}_{2}$ and aerosol $\mathrm{SO}_{4}^{2-}$. the regionality of the aerosol acidity and $\mathrm{SO}_{4}^{2-}$ phenomena observed, the sporadic behavior of $\mathrm{SO}_{2}$ concentrations, and the wind directions and air-mass trajectories associated with high and low $\mathrm{SO}_{4}^{2-}$ concentrations (Pierson et al., 1980; Samson, 1980). The agreement between the present study and 1977 adds further evidence that the phenomena reported are not an anomaly as originally sometimes supposed, but instead may be typical of summertime in this part of the country

Data on $\mathrm{O}_{3}$, lacking in the 1977 study, were considered important because of the perception (e.g. Lioy and Lippmann, 1986; Lioy et al., 1979, 1980, 1982; Wolff, 1979; Wolff et al., 1979a, 1979b, 1981, 1982) that $\mathrm{O}_{3}$ is central to the summertime haze episodes in the Northeast. Undoubtedly this perception is correct; but the amount of $\mathrm{O}_{3}$ throughout the present study (and, evidently, in general in this region during the summer) is in such overwhelming excess of the $\mathrm{NO}_{x}$ and $\mathrm{SO}_{2}$ at all times (e.g. Table 2) that the $\mathrm{O}_{3}$ concentration must surely be irrelevant to the $\mathrm{SO}_{2} \rightarrow \mathrm{SO}_{4}^{2-}$ conversion or to $\mathrm{HNO}_{3}$ formation except possibly as a surrogate for concentrations of trace oxidants such as $\mathrm{H}_{2} \mathrm{O}_{2}$ or $\mathrm{OH}$. High summertime $\mathrm{O}_{3}$ and $\mathrm{SO}_{4}^{2-}$ levels are said (Lioy et al., 1979, 1980; Whelpdale, 1978; Wolff, 1979; Wolff and Lioy, 1980; Wolff et al., 1979b, 1982) to be associated with flow around the back side of a high pressure system moving southeastward; and indeed the sites were on the back side of such a system during the period 23-25 August, which did deliver moderately high $\mathrm{SO}_{4}^{2-}$ concentrations to the sites and gave the highest $\mathrm{SO}_{4}^{2-} / \mathrm{SO}_{2}$ ratios seen in the study; but the $\mathrm{O}_{3}$ levels in this period were only about $55 \mathrm{ppb}$ (2140 nanomoles $\mathrm{m}^{-3}$ ), or about at the study average. High $\mathrm{H}^{+}$and $\mathrm{SO}_{4}^{2}$ on the night of 18 August (run 24) were accompanied by relatively low $\mathrm{O}_{3}(42 \mathrm{ppb})$. The 
correlation between instantaneous $b_{\text {scat }}$ and $\mathrm{O}_{3}$ was unexceptional $(r=0.42)$, as was the correlation of runaverage $\mathrm{O}_{3}$ with $\mathrm{H}^{+}, \mathrm{SO}_{4}^{2-}$, or $b_{\text {scat }}$ (Table 3). Other recent evidence is said (Lioy and Lippmann, 1986) to suggest that increases in acid and $\mathrm{O}_{3}$ concentrations are not always correlated.

We have considered the idea (Hidy et al., 1978; Whelpdale, 1978; Wolff, 1979) that high regional summertime $\mathrm{SO}_{4}^{2-}$ in the .Northeast is linked with synoptic-scale circulation of warm humid air of maritime tropical (mT) origin moving up on southerly and westerly winds into the Midwest and on into the Northeast. Changes in $\mathrm{SO}_{4}^{2-}$ with temperature and dewpoint that support this picture have been noted (Hidy et al., 1978). However, using dewpoint and ambient temperature as the diagnostics, we find little encouragement for this idea in the present study. The highest dewpoints are indeed all associated with westerly trajectories. The correlations of run-average dewpoint with $b_{\text {scat }}$ and $\mathrm{SO}_{4}^{2-}$ are fairly strong $(r=0.75$ and 0.72 , respectively). But the issue is confounded by the circumstance that the trajectories with the highest dewpoints all traverse the $\mathrm{SO}_{2}$ source region as well. And the overlap between highest dewpoint and highest $\mathrm{SO}_{4}^{2-}$ is by no means complete, chiefly because the high-dewpoint trajectories with high wind speeds are accompanied by $\mathrm{SO}_{4}^{2-}$ levels that are sometimes only average; trajectory wind speed is important to $\mathrm{SO}_{4}^{2-}$ levels but evidently not to dewpoint. The trajectories associated with the four highest run-average dewpoints (and moderately high $\mathrm{SO}_{4}^{2-}$ ) all passed over Lake Michigan and Lake Erie on the way to Allegheny. Highest ambient temperatures were associated with westerly trajectories but not with maximum $\mathrm{SO}_{4}^{2-}$.

Since the aerosol $\mathrm{H}^{+}$reported in the present study (and by others) is an important part of the total of the atmospheric acidity, it is necessary to ask how this $\mathrm{H}^{+}$, as reported, relates to the $\mathrm{H}^{+}$actually existing in the aerosol particle or droplet. This droplet consists essentially of $\left(\mathrm{NH}_{4}\right)_{x} \mathrm{H}_{(2-x)} \mathrm{SO}_{4}$ (aq) with $0 \leqslant x \leqslant 2$. In the laboratory measurement the supposed aqueous solution constituting the aerosol droplet undergoes a dilution of $\geqslant 10^{3}$-fold. The $\mathrm{HSO}_{4}^{-}$ion $\left(K_{d}=0.012\right)$ is completely dissociated in this situation. Now let us first imagine an $\mathrm{H}_{2} \mathrm{SO}_{4}(\mathrm{aq})$ aerosol $(x=0)$ in vaporpressure equilibrium with ambient air at $25^{\circ} \mathrm{C}$ and at r.h. $75 \%$ (the time-average r.h. that was measured at Allegheny and Laurel combined). From Stokes and Robinson (1949) we find that the $\mathrm{H}_{2} \mathrm{SO}_{4}$ concentration at equilibrium would be about $3.94 \mathrm{M}$. From the $K_{\mathrm{d}}$, at this concentration we would have $\left[\mathrm{H}^{+}\right]$ $=3.95 \mathrm{M}(\mathrm{pH}=-0.6),\left[\mathrm{HSO}_{4}^{-}\right]=3.93 \mathrm{M},\left[\mathrm{SO}_{4}^{2-}\right]$ $=0.012 \mathrm{M}$. If the species in the aerosol is $\mathrm{NH}_{4} \mathrm{HSO}_{4}(\mathrm{aq})$, then we find the $\mathrm{HSO}_{4}^{-}$about half dissociated: $\left[\mathrm{H}^{+}\right]=\left[\mathrm{SO}_{4}^{2-}\right] \simeq 1.7 \mathrm{M}, \quad\left[\mathrm{HSO}_{4}^{-}\right]$ $\sim 2.3 \mathrm{M}$. Thus the $\mathrm{H}^{+}$and $\mathrm{SO}_{4}^{2-}$ neq $\mathrm{m}^{-3}$ results reported in this study are 'infinite-dilution' values; the concentrations actually existing in the aerosol will be less for $\mathrm{H}^{+}$(though not an order of magnitude less), and less for $\mathrm{SO}_{4}^{2-}$, much of the reported $\mathrm{H}^{+}$and $\mathrm{SO}_{4}^{2-}$ actually being present as $\mathrm{HSO}_{4}^{-}$.

The fact that there seems to have been initially present only enough ambient $\mathrm{NH}_{3}(\mathrm{~g})$ to neutralize about $35 \%$ of the aerosol $\mathrm{H}_{2} \mathrm{SO}_{4}$ raises an interesting question: what would happen to the atmospheric acidity if $\mathrm{SO}_{2}$ emissions were further curtailed? There is currently some debate about whether a given decrease in $\mathrm{SO}_{2}$ emissions will cause a proportionate decrease in acid deposition, it being thought in some quarters that large decreases in $\mathrm{SO}_{2}$ emissions would be necessary before any benefit in acid deposition could begin to be realized because in the atmospheric processes involved the $\mathrm{SO}_{2}$ is present in excess. We are not dealing with that question, but rather the question of neutralization of the $\mathrm{H}_{2} \mathrm{SO}_{4}$ however produced. Thus, if $\mathrm{SO}_{2}$ emissions were curtailed in such a way as to decrease the amount of $\mathrm{SO}_{4}^{2-}$ produced, and there were no other changes, then there would be disproportionately large decrease in atmospheric acidity. For example, if the ambient $\mathrm{NH}_{3}(\mathrm{~g})$ presently can titrate $35 \%$ of the aerosol $\mathrm{H}_{2} \mathrm{SO}_{4}$ formed, a halving of the latter would drop the residual aerosol acidity by a factor of 4.

\section{CONCLUSIONS}

This paper explores some air chemistry and meteorology from the standpoint of atmospheric acidity in a summertime study at two mountaintop sites (Allegheny Mountain and Laurel Hill) in southwestern Pennsylvania. (Deposition during the study is discussed in other papers.) The sites are $\sim 150 \mathrm{~km}$ downwind of the highest density of $\mathrm{SO}_{2}$ emissions in the U.S. and within the region of the greatest wet/dry acid deposition flux in all of the Northeast, in an area where environmental damage ascribed to acid deposition has been reported.

With $\mathrm{SO}_{2}$ taken to represent potentially two $\mathrm{H}^{+}$ per $\mathrm{SO}_{2}$ molecule, the average atmospheric acidity from $\mathrm{SO}_{2}(\mathrm{~g})$, aerosol $\mathrm{H}^{+}$and $\mathrm{HNO}_{3}(\mathrm{~g})$ was $\sim 1200$ neq $\mathrm{m}^{-3}$ all together, generally in the order $\mathrm{SO}_{2}>$ aerosol $\mathrm{H}^{+}>\mathrm{HNO}_{3}$, with enormous temporal variabilities, occasionally with $\mathrm{HNO}_{3}>$ aerosol $\mathrm{H}^{+}$, rarely with aerosol $\mathrm{H}^{+}>\mathrm{SO}_{2}$, and never with $\mathrm{HNO}_{3}>\mathrm{SO}_{2}$. Amounts of $\mathrm{NH}_{3}(\mathrm{~g})$ and other acidneutralizing substances (e.g. alkaline soil elements) were practically negligible by comparison.

The behavior of aerosol $\mathrm{H}^{+}$in strong association with aerosol $\mathrm{SO}_{4}^{2-}$ implies an aqueous $\mathrm{H}_{2} \mathrm{SO}_{4}$ aerosol in varying stages of neutralization by atmospheric $\mathrm{NH}_{3}(\mathrm{~g})$. The degree of neutralization depended primarily on the $\mathrm{SO}_{4}^{2-}$ concentration, with higher $\mathrm{H}^{+} / \mathrm{SO}_{4}^{2-}$ ratios at higher $\mathrm{SO}_{4}^{2-}$ concentrations. Allegheny, usually $1-2 \mathrm{~h}$ downwind of Laurel, tended to have $\sim 7 \%$ higher $\mathrm{NH}_{4}^{+} / \mathrm{SO}_{4}^{2-}$ ratios and $\sim 6 \%$ lower $\mathrm{H}^{+} / \mathrm{SO}_{4}^{2-}$ ratios, indicative of very slow ongoing neutralization. Average $\mathrm{H}^{+} / \mathrm{SO}_{4}^{2-}$ mole ratio was 1.0. A fully neutralized $\left(\mathrm{NH}_{4}\right)_{2} \mathrm{SO}_{4}$ aerosol was never encountered. In general the amount of $\mathrm{HNO}_{3}$, 
$\mathrm{NH}_{3}$ and aerosol $\mathrm{H}^{+}$and $\mathrm{NH}_{4}^{+}$present was consistent with the proposition that the amount of summertime anthropogenic acid $\left(\mathrm{H}_{2} \mathrm{SO}_{4}, \mathrm{HNO}_{3}\right)$ pollution in this part of the Northeast currently exceeds the acidneutralizing capacity of the air by a factor of 2 or 3 .

The stoichiometry between $\mathrm{H}^{+}, \mathrm{NH}_{4}^{+}$and $\mathrm{SO}_{4}^{2-}$ in the aerosol, and the mass balance between these species and gravimetric mass with allowance for water of hydration, indicate that the aerosol was generally an aqueous $\left(\mathrm{NH}_{4}\right)_{x} \mathrm{H}_{2}-\mathrm{SO}_{4}$ aerosol with only minor amounts of other constituents except carbon. There was very little aerosol $\mathrm{NO}_{3}^{-}$, consistent with the acidic nature of the aerosol; some $90 \%$ of the inorganic $\mathrm{NO}_{3}^{-}$ on the average existed as $\mathrm{HNO}_{3}(\mathrm{~g})$.

The aerosol $\mathrm{SO}_{4}^{2-}$ episodes occurred in cycles of 7 or 8 days on the average and lasted several days each time, usually without a great deal of hour-to-hour fluctuation (as judged by $b_{\text {scat }}$, which was found to be a real-time surrogate for aerosol $\mathrm{SO}_{4}^{2-}$ and $\mathrm{H}^{+}$), and with a spatial scale of $\gg 35 \mathrm{~km}$, in line with the already-recognized regional nature $\left(>10^{5} \mathrm{~km}^{2}\right)$ of such episodes. Aerosol $\mathrm{H}^{+}$exhibited the same pattern as $\mathrm{SO}_{4}^{2-}$, signifying that $\mathrm{H}^{+}$, like $\mathrm{SO}_{4}^{2-}$, was produced by regional $\mathrm{SO}_{2} \rightarrow \mathrm{H}_{2} \mathrm{SO}_{4}$ atmospheric conversion and advection to the sites, rather than emitted or formed locally. $\mathrm{SO}_{2}$ behaved quite differently, existing largely in short-lived bursts (believed to represent fumigation by plumes from the numerous coal-fired power plants upwind), and in general decoupled from the regional $\mathrm{H}^{+}$and $\mathrm{SO}_{4}^{2-}$. The $\mathrm{SO}_{2}$ sources proved not to be significant sources of directly-emitted lightscattering aerosol or $\mathrm{SO}_{4}^{2-}$. Correlations with $\mathrm{Se}$ indicate that the main origin of the $\mathrm{SO}_{2}$, and ultimately of the regional $\mathrm{H}^{+}$and $\mathrm{SO}_{4}^{2-}$, was coal combustion.

One instance was encountered of inter-site transport with growing $b_{\text {seat }}$ and marginally declining $\mathrm{SO}_{2}$; with $b_{\text {scal }}$ as a surrogate for $\mathrm{SO}_{4}^{2-}$ it was calculated that daytime $\mathrm{SO}_{2}$ oxidation and dry deposition rate coefficients were $\sim 0.05$ and $\leqslant 0.1 \mathrm{~h}^{-1}$, respectively.

The $\mathrm{HNO}_{3}$ (and total nitrate) pattern was like the $\mathrm{SO}_{4}^{2-}$ pattern but with more day-to-day and inter-site variability, signifying a regional pollutant with a local component and faster formation/removal rates. $\mathrm{HNO}_{3} / \mathrm{SO}_{2} / \mathrm{Se}$ intercorrelations indicate that the local $\mathrm{HNO}_{3}$ source is the power plants. $\mathrm{HNO}_{3}$ and $\mathrm{SO}_{2}$ responded much more rapidly to general wind changes than did aerosol $\mathrm{H}^{+}$or $\mathrm{SO}_{4}^{2-}$, again indicating the regionality of the latter two. Thus the atmospheric acidity consisted of regional aerosol $\mathrm{H}^{+}$ (associated with $\mathrm{SO}_{4}^{2-}$ ), regional and local $\mathrm{HNO}_{3}(\mathrm{~g})$, and substantially local $\mathrm{SO}_{2}(\mathrm{~g})$.

Poor correlations between $\mathrm{HNO}_{3}$ (or $\mathrm{NO}_{x}$ ) and $\mathrm{Pb}$ made it impossible to demonstrate an automotive contribution to the $\mathrm{HNO}_{3}$. One would expect it to have been significant but not major in this area.

In addition, there was a significant role of local photochemistry in $\mathrm{HNO}_{3}$ formation; $\mathrm{HNO}_{3}$ concentrations were lower at night, despite a much lower night-time deposition velocity and a lack of diurnal variation in $\mathrm{O}_{3}$. This inference is supported by correlations among $\mathrm{HNO}_{3}, \mathrm{O}_{3}$ and PAN. (PAN, a photochemical product formed in polluted air masses, decayed at night in the present study with $t_{1 / 2} \sim 7$ to 8 h.) Photochemical production of $\mathrm{SO}_{4}^{2-}$ was also suggested by modest correlations of $b_{\text {scat }}$ with PAN and $\mathrm{O}_{3}$; but the local component of the photochemical $\mathrm{SO}_{2} \rightarrow \mathrm{SO}_{4}^{2-}$ conversion could not have been large compared to the $\mathrm{SO}_{4}^{2-}$ formed at a distance and advected to the site, since there was no significant night/day alternation of $\mathrm{SO}_{2} /\left(\mathrm{SO}_{2}+\mathrm{SO}_{4}^{2-}\right)$ ratio, $\mathrm{H}^{+} / \mathrm{SO}_{4}^{2-}$ ratio, or $\mathrm{H}^{+} / \mathrm{NH}_{4}^{+}$ratio.

A large excess of $\mathrm{O}_{3}$ relative to $\mathrm{SO}_{2}$ and $\mathrm{NO}_{x}$ was present at all times. Clearly there existed an oxidizing atmosphere, conducive to acid formation. By the same token, $\mathrm{O}_{3}$ itself must not have been a limiting oxidant in acid formation.

The size distributions of aerosol $\mathrm{H}^{+}$and $\mathrm{SO}_{4}^{2}$ (and $\mathrm{NH}_{4}^{+}$) were substantially the same, further illustrating their close association, with MMED $\sim 0.7 \mu \mathrm{m}$. The particles are in the optimum size range for efficient light scattering (much of it evidently attributable to aerosol $\mathrm{H}_{2} \mathrm{O}$ ) and inefficient wet or dry removal. Thus a close relationship between aerosol acidity and visibility degradation was expected and found. And the suggestion by Tanner et al. (1984), that strong acids may be available for long-distance transport in the lower troposphere, must certainly be correct at least with regard to aerosol $\mathrm{H}^{+}$. Low $\mathrm{HNO}_{3}$ deposition velocities found in this study under stratified nighttime conditions $\left(0.24 \mathrm{~cm} \mathrm{~s}^{-1}\right.$; Pierson et al., 1986) indicate that $\mathrm{HNO}_{3}$ too can be transported at night.

The highest $\mathrm{SO}_{4}^{2-}$ and aerosol $\mathrm{H}^{+}$were associated with winds from the west. Not all westerly trajectories through the $\mathrm{SO}_{2}$ source region lying to the west gave high $\mathrm{SO}_{4}^{2-}$, however, but rather more often the slowmoving ones. Wind speed upwind was important; in general, high concentrations of $\mathrm{H}^{+}, \mathrm{SO}_{4}^{2-}, \mathrm{HNO}_{3}$ and $\mathrm{SO}_{2}$ were associated with stagnation and meandering slow-moving trajectories from the west, while low values were associated with some fast-moving trajectories from that direction and with air masses from northerly directions. Maximum $\mathrm{H}^{+}$and $\mathrm{SO}_{4}^{2-}$ concentrations tended to be associated with low wind speeds $>24 \mathrm{~h}$ upstream, suggesting $\mathrm{SO}_{2}$ accumulation during stagnation over a source region followed by enough transport time $(>24 \mathrm{~h})$ to permit substantial $\mathrm{SO}_{2} \rightarrow \mathrm{H}_{2} \mathrm{SO}_{4}$ conversion en route. $\mathrm{HNO}_{3}$ and aerosol $\mathrm{NH}_{4}^{+}$showed qualitatively similar behavior but their association with upstream inverse wind speed was weaker. Wind speed may also have been a factor in the lower concentrations observed in 1977 when average speed was over twice as high.

Fairly high $\mathrm{H}^{+}$and $\mathrm{SO}_{4}^{2-}$, but only moderate $\mathrm{HNO}_{3}$ and $\mathrm{O}_{3}$, and low $\mathrm{SO}_{2}$, were encountered when air reached the sites from $\mathrm{SE}$ on the back side of a high pressure system centered to the $\mathrm{N}$ and moving $\mathrm{SE}$. This situation also gave especially high $\mathrm{SO}_{4}^{2-} / \mathrm{SO}_{2}$ ratios, perhaps more through $\mathrm{SO}_{2} \rightarrow \mathrm{SO}_{4}^{2-}$ conversion than through $\mathrm{SO}_{2}$ deposition during the long trip 
from the source region. Evidently $\mathrm{HNO}_{3}$ transport was not particularly efficient. $\mathrm{High} \mathrm{SO}_{4}^{2-} / \mathrm{SO}_{2}$ ratios and substantial PAN levels indicated an aged photochemical air mass.

Very high concentrations of all pollutants including $\mathrm{H}^{+}, \mathrm{SO}_{4}^{2-}, \mathrm{HNO}_{3}, \mathrm{SO}_{2}, \mathrm{O}_{3}$ and PAN developed during a severe local stagnation interval, indicating that local sources under sufficiently stagnant conditions can give rise to pronounced atmospheric acidity. Thus we identify three meteorological regimes for high atmospheric acidity: (1) slow westerly winds, with stagnation and meandering over $\mathrm{SO}_{2}$ source areas lying to the west, (2) local stagnation, and (3) regional transport around to the back side of a high pressure system. Upwind rain is also a factor, especially when it occurs between the source areas and the sampling sites. In most of the cases with maximum atmospheric acidity there had been no rain for at least $72 \mathrm{~h}$ upwind.

Agreement between the results of this study and the earlier one in 1977 at the same site, as well as other studies in the Northeast, indicate that the situation herein described is not anomalous and indeed could be quite typical for summertime rural conditions in that region.

Acknowledgements-We are pleased to acknowledge the assistance of the Pennsylvania Turnpike Commission in providing access and electric power at the two sites and helping us set up the experiment; we are especially indebted to Warren E. Kipp, Robert E. Davis, Nevin A. Miller, Carl Baker and the crew at the Allegheny Mountain Tunnel, and the Chief Engineer and Deputy Executive Director of the Turnpike Commission, Robert H. Klucher. At Ford, we are indebted to Y. T. Liu, Gerald E. Fisher and Clifford N. Montreuil for their participation in the chemical analysis. Ford participants in the field experiment itself included Karen M. Adams, James W. Butler, Ann C. Cleary, James C. Dziadosz, Larry P. Haack, Thomas J. Korniski, Fred E. McKelvy, William K. Okamoto and Michael J. Rokosz. Jeffrey M. Masters of the University of Michigan participated in the experiment and handled the on-site meteorology. Perry J. Samson of the University of Michigan assisted in the trajectory analysis and meteorology. We thank William J. Courtney of Northrop Services and Thomas G. Dzubay, Charles W. Lewis and Robert K. Stevens of EPA/ESRL for their collaboration including field intercalibration and the use of their instruments. We are grateful to E. Eugene Weaver (retired from Ford) and Adele Weaver for their participation in the field experiment. The work was supported in part by the National Science Foundation under Industry/University Cooperative Research Grant No. ATM8507282 to the University of Michigan.

\section{REFERENCES}

Altshuller A. P. (1976) Regional transport and transformation of sulfur dioxide to sulfates in the U.S. J. Air Pollut. Control Ass. 26, 318-324.

Appel B. R., Tokiwa Y. and Haik M. (1981) Sampling of nitrates in ambient air. Atmospheric Environment 15, 283-289.

Barrie L. A., Anlauf K., Wiebe H. A. and Fellin P. (1984) Acidic pollutants in air and precipitation at selected rural locations in Canada. In Deposition Both Wet and Dry (edited by Hicks B. B.), Chapter 2, pp. 15-35. Acid Precipitation Series, Vol. 4. Butterworth, Boston.
Barrie L. A. and Hales J. M. (1984) The spatial distributions of precipitation acidity and major ion wet deposition in North America during 1980. Tellus 36B, 333-355.

Brosset C. (1978) Water-soluble sulphur compounds in aerosols. Atmospheric Environment 12, 25-38.

Brosset C. (1980) Types of transport episodes in northern Europe. Ann. N.Y. Acad. Sci. 338, 389-398.

Cadle S. H., Groblicki P. J. and Mulawa P. A. (1983) Problems in the sampling and analysis of carbon particulates. Atmospheric Environment 17, 593-600.

Chang T. Y. (1986) Estimates of nitrate formation in rain and snow systems. J. geophys. Res. 91, 2805-2818.

Chang T. Y., Kuntasal G. and Pierson W. R. (1987) Nighttime $\mathrm{N}_{2} \mathrm{O}_{5} / \mathrm{NO}_{3}$ chemistry and nitrate in dew water. Atmospheric Environment 21, 1345-1351.

Charlson R. J., Covert D. S., Larson T. V. and Waggoner A P. (1978) Chemical properties of tropospheric sulfur aerosols. Atmospheric Environment 12, 39-53.

Clark T. L. (1980) Annual anthropogenic pollutant emissions in the United States and southern Canada east of the Rocky Mountains. Atmospheric Environment 14, 961-970. Cunningham P. and Johnson S. A. (1976) Spectroscopic observation of acid sulfate in atmospheric particulate samples. Science 191, 77-79.

DeWalle D. R., Dinicola R. S. and Sharpe W. E. (1985) Geologic models for predicting baseflow alkalinity in headwater streams on Laurel Hill in Pennsylvania. In Hydrological and Hydrogeochemical Mechanisms and Model Approaches to the Acidification of Ecological Systems, Proceedings of the International Programme (IHP) Workshop. Uppsala, 15-16 September 1984 (edited by Johansson I.), Nordic Hydrological Programme Report No. 10 pp. 107-108. The Coordinating Committee for Hydrology in Norden, NFRs Committee for Hydrology, Sweden.

Dzubay T. G., Snyder G. K., Reutter D. J. and Stevens R. K. (1979) Aerosol acidity determination by reaction with ${ }^{14} \mathrm{C}$ labclled aminc. Atmospheric Environment 13, 1209-1212.

Ferek R. J., Lazrus A. L., Haagenson P. L. and Winchester J. W. (1983) Strong and weak acidity of aerosols collected over the northeastern United States. Envir. Sci. Technol. $17,315-324$.

Ferm M. (1979) Method for determination of atmospheric ammonia. Atmospheric Environment 13, 1385-1393.

Ferman M. A., Wolff G. T. and Kelly N. A. (1981) The nature and sources of haze in the Shenandoah Valley/Blue Ridge Mountains area. J. Air Pollut. Control Ass. 31, 1074-1082.

Gorse R. A., Jr. (1984) On-road emission rates of carbon monoxide, nitrogen oxides and gaseous hydrocarbons. Envir. Sci. Technol. 18, 500-507.

Grosjean D. (1988) Aldehydes, carboxylic acids and inorganic nitrate during the NSMCS. Atmospheric Environment 22, 1637-1648.

Hara H., Kurita M. and Okita T. (1982) Ammonia denuder for field sampling of sulfuric acid particles. Atmospheric Environment 16, 1565-1566.

Heffter J. L. (1980) Air Resources Laboratories atmospheric transport and dispersion model. NOAA Technical Memorandum ERL ARL-81, National Oceanic and Atmospheric Administration Air Resources Laboratory, Silver Spring, Maryland, February 1980.

Hicks B. B., Lyons W. B., Mayewski P. A. and Stensland G. J. (1984) Deposition monitoring. In The Acidic Deposition Phenomenon and Its Effects: Critical Assessment Review Papers Volume I-Atmospheric Sciences, U.S. Environmental Protection Agency Report EPA-600/8-83-016AF (edited by Altshuller A. P. and Linthurst R. A.), Chapter A-8. U.S. Government Printing Office, Washington, D.C.

Hidy G. M., Mueller P. K. and Tong E. Y. (1978) Spatial and temporal distributions of airborne sulfate in parts of the United States. Atmospheric Environment 12, 735-752.

Holdren M. W. and Spicer C. W. (1984) Field compatible 
calibration procedure for peroxyacetyl nitrate. Envir. Sci. Technol. 18, 113-116.

Huntzicker J. J., Johnson R. L., Shah J. J. and Cary R. A. (1982) Analysis of organic and elemental carbon in ambient aerosols by a thermal-optical method. In Particulate Carbon: Atmospheric Life Cycle (edited by Wolff G. T. and Klimisch R. L.), pp. 79-88. Plenum Publishing, New York.

Husain I., Webher I. S., Canelli F., Dutkiewicz V. A. and Halstead J. A. (1984) $\mathrm{Mn} / \mathrm{V}$ ratio as a tracer of aerosol $\mathrm{SO}_{4}^{2-}$ transport. Atmospheric Environment 18, 1059-1071.

Japar S. M., Brachaczek W. W., Gorse R. A., Jr., Norbeck J. M. and Pierson W. R. (1985) Dry deposition of nitric acid and sulfur dioxide to a nylon surrogate surface. Presented at Muskoka 85: International Symposium on Acidic Precipitation, Minet, Ontario, Federal Govermment of Canada, 16-20 September 1985.

Japar S. M., Brachaczek W. W., Gorse R. A., Jr., Norbeck J. M. and Pierson W. R. (1986) The contribution of elemental carbon to the optical properties of rural atmospheric aerosols. Atmospheric Environment 20, 1281-1289.

Kawamura K. and Kaplan I. R. (1987) Motor exhaust emissions as a primary source for dicarboxylic acids in Los Angeles ambient air. Envir. Sci. Technol. 21, 105-110.

Kawamura K., Ng L-L. and Kaplan I. R. (1985) Determination of organic acids $\left(C_{1}-C_{10}\right)$ in the atmosphere, motor exhausts, and engine oils. Envir. Sci. Technol. 19, $1082 \cdots 1086$

Keeler G. L., Brachaczek W. W., Gorse R. A., Jr., Japar S. M. and Pierson W. R. (1988) Effect of ambient humidity on dichotomous sampler coarse/fine particle ratios. Atmospheric Environment 22, 1715-1720.

Keene W. C. and Galloway J. N. (1984) Organic acidity in precipitation of North America. Atmospheric Environment 18, 2491-2497.

Keene W. C., Galloway J. N. and Holden J. D., Jr. (1983) Measurement of weak organic acidity in precipitation from remote areas of the world. J. geophys. Res. 88, $5122-5130$

Kelly N. A., Wolff G. T. and Ferman M. A. (1984) Sources and sinks of ozone in rural areas. Atmospheric Environment 18, 1251-1266

Lioy P. J. and Lippmann M. (1986) Measurement of exposure to acidic sulfur aerosols. In Aerosols: Research, Risk Assessment and Control Strategies, Proceedings of the Second U.S.-Dutch International Symposium, Williamsburg, Virginia, 19-25 May 1985 (edited by Lee S. D., Schneider T., Grant L. D. and Verkerk P. J.), Chapter 56 (pp. 743-752). U.S. Environmental Protection Agency and the Ministry of Housing, Physical Planning, and the Environment of The Netherlands. Lewis Publishers, Chelsea, Michigan

Lioy P. J., Wolff G. T. and Leaderer B. P. (1979) A discussion of the New York Summer Aerosol Study, 1976. Ann. N.Y. Acad. Sci. 322, 153-165.

Lioy P. J., Samson P. J., Tanner R. L., Leaderer B. P. Minnich T. and Lyons W. (1980) The distribution and transport of sulfate "species" in the New York metropolitan area during the 1977 summer aerosol study. Atmospheric Environment 14, 1391-1407.

Lioy P. J., Mallon R. P., Lippmann M., Kneip T. J. and Samson P. J. (1982) Factors affecting the variability of summertime sulfate in a rural area using Principal Component Analysis. J. Air Pollut. Control Ass. 32, 1043-1047.

Lynch J. A., Corbett E. S. and Rishel G. B. (1984) Atmospheric Deposition: Spatial and Temporal Variation in Pennsylvania-1983. Publication No. LW 8405A, Institute for Land and Water Resources, Pennsylvania State University, Universily Park, Pennsylvania.

Lynch J. A., Corbett E. S. and Rishel G. B. (1985) Atmospheric Deposition: Spatial and Temporal Variation in Pennsylvania-1984. Publication No. LW8505, Institute for Land and Water Resources, Pennsylvania State University, University Park. Pennsylvania.
Morandi M. T., Kneip T. J., Cobourn W. G., Husar R. B. and Lioy P. J. (1983) The measurement of $\mathrm{H}_{2} \mathrm{SO}_{4}$ and other sulfate species at Tuxedo, New York with a thermal analysis flame photometric detector and simultaneously collected quartz filter samples. Atmospheric Entronment 17, 843-848.

Mueller P. K., Hidy G. M., Warren K., Lavery T. F. and Baskett R. L. (1980) The occurrence of atmospheric aernsols in the northeastern United States. Ann. N.Y. Acad. Sci. 338, $463-482$.

Olsen A. R. and Slavich A. L. (1986) Acid Precipitation in North America: 1983 Annual Data Summary from Acid Deposition System Data Base, U.S. Environmental Protection Agency Report EPA/600/4-85/061 (Environmental Monitoring Systems Laboratory, Office of Research and Development), NTIS Document No. PB86166345, National Technical Information Service, Washington, D.C

Pierson W. R. (1981) Comment on Lioy et al., 1981. Atmospheric Environment 15, 1335.

Pierson W. R. and Brachaczek W. W. (1983) Particulate matter associated with vehicles on the road. II. Aerosol Sci. Technol. 2, 1-40.

Pierson W. R. and Brachaczek W. W. (1988) Coarse- and fine-particle atmospheric nitrate and $\mathrm{HNO}_{3}(\mathrm{~g})$ in Claremont, California, during the 1985 Nitrogen Species Methods Comparison Study. Atmospheric Environment 22, 1665-1668.

Pierson W. R. and Brachaczek W. W. (1989) Dew chemistry and acid deposition in Glendora, California, during the 1986 Carbonaceous Species Methods Comparison Study. Third International Conference on Carbonaceous Particles in the Atmosphere, Berkeley, California, 5-8 October 1987; Aerosol Sci. Technol. (submitted).

Pierson W. R., Brachaczek W. W., Truex T. J., Butler J. W. and Korniski T. J. (1980) Ambient sulfate measurements on Allegheny Mountain and the question of atmospheric sulfate in the northeastern United States. Ann. N.Y. Acad. Sci. 338, 145-173.

Pierson W. R., Brachaczek W. W., Gorse R. A., Jr., Japar S. M. and Norbeck J. M. (1986) On the acidity of dew. $J$. geophys. Res. 91, 4083-4096.

Pierson W. R., Brachaczek W. W., Gorse R. A., Jr., Japar S. M., Norbeck J. M. and Keeler G. J. (1987) Acid rain and atmospheric chemistry at Allegheny Mountain. Envir. Sci. Technol. 21, 679-691.

Pierson W. R., Brachaczek W. W., Japar S. M., Cass G. R. and Solomon P. A. (1988) Dry deposition and dew chemistry in Claremont, California, during the 1985 Nitric Acid Intercomparison Study. Atmospheric Environment 22, $1657-1663$

Poirot R. L. and Wishinski P. R.(1986) Visibility, sulfate and air mass history associated with the summertime aerosol in northern Vermont. Atmospheric Environment 20, 1457-1470.

Rahn K. and Lowenthal D. H. (1985) Pollution aerosol in the Northeast: Northeastern-Midwestern contributions. Science 228, 275-284.

Samson P. J. (1980) Trajectory analysis of summertime sulfate concentrations in the northeastern United States. $J$ appl. Met. 19, 1382-1394.

Sharpe W. E., Liebfried V. G., Kimmel W. G. and DeWalle D. R. (1987) The relationship of water quality and fish occurrence to soils and geology in an area of high hydrogen and sulfate ion deposition. Wat. Resources Bull. 23, 37-46. Cited by Haines T. M. in Acid Deposition LongTerm Trends, National Research Council Committee on Monitoring and Assessment of Trends in Acid Deposition (Gibson J. H., Chairman), Chapter 8, pp. 304-306. National Academy Press, Washington, D.C.

Sharpe W. E., DeWalle D. R., Liebfried R. T., Dinicola R. S., Kimmel W. G. and Sherwin L. S. (1984) Causes of acidification of four streams on Laurel Hill in southwestern 
Pennsylvania. J. Envir. Quality 13, 619-631.

Shaw R. W., Jr., Stevens R. K., Bowermaster J., Tesch J. W. and Tew E. (1982) Measurements of atmospheric nitrate and nitric acid: the denuder difference experiment. $A t$ mospheric Environment 16, 845-853.

Smith W. B., Wilson R. R., Jr. and Harris D. B. (1979) A fivestage cyclone system for in situ sampling. Envir. Sci. Technol. 13, 1387-1392.

Spicer C. W., Howes J. E., Jr., Bishop T. A., Arnold L. H. and Stevens R. K. (1982) Nitric acid measurement methods: an intercomparison. Atmospheric Environment 16, 1487-1500.

Spicer C. W. (1986) Private communication. Battelle Columbus Laboratories, Columbus, Ohio.

Stevens R. K., Dzubay T. G., Russwurm G. and Rickel D. (1978) Sampling and analysis of atmospheric sulfates and related species. Atmospheric Environment 12, 55-68.

Stevens R. K., Dzubay T. G., Shaw R. W., Jr., McClenny W. A., Lewis C. W. and Wilson W. E. (1980) Characterization of the aerosol in the Great Smoky Mountains. Envir. Sci. Technol. 14, 1491-1498.

Stevens R. K., Dzubay T. G., Lewis C. W. and Shaw R. W., Jr. (1984) Source apportionment methods applied to the determination of the origin of ambient aerosols that affect visibility in forested areas. Atmospheric Environment 18, 261-272.

Stokes R. H. and Robinson R. A. (1949) Standard solutions for humidity control at $25^{\circ} \mathrm{C}$. Indust. Engrg. Chem. 41, 2013.

Tanner R. L., Cederwall R., Garber R., Leahy D., Marlow W., Meyers R., Phillips M. and Newman L. (1977) Separation and analysis of aerosol sulfate species at ambient concentrations. Atmospheric Environment 11, 955-966.

Tanner R. L., Leaderer B. P. and Spengler J. D. (1981) Acidity of atmospheric aerosols. Atmospheric Environment 15, 1150-1153.

Tanner R. L., Kumar R. and Johnson S. (1984) Vertical distribution of aerosol strong acid and sulfate in the atmosphere. J. geophys. Res. 89, 7149-7158.

Weiss R. E., Larson T. V. and Waggoner A. P. (1982) In situ rapid-response measurement of $\mathrm{H}_{2} \mathrm{SO}_{4} /\left(\mathrm{NH}_{4}\right)_{2} \mathrm{SO}_{4}$ aerosols in rural Virginia. Envir. Sci. Technol. 16, 525-532

Whelpdale D. M. (1978) Large-scale atmospheric sulfur studies in Canada. Atmospheric Environment 12, 661-670.

Wolf G. T. (1979) The question of sulfates - a conference summary. J. Air Pollut. Control Ass. 29, 26-27.

Wolff G. T. (1984) On the nature of nitrate in coarse continental aerosols. Atmospheric Environment 18, 977-981.

Wolff G. T. and Lioy P. J. (1980) Development of an ozone river associated with synoptic scale episodes in the eastern U.S. Envir. Sci. Technol. 14, 1257-1261.

Wolff G. T., Lioy P. J., Leaderer B. P., Bernstein D. M. and Kleinman M. T. (1979a) Characterization of aerosols upwind of New York City: I. Transport. Ann. N.Y. Acad. Sci. 322, 57-71.

Wolff G. T., Monson P. R. and Ferman M. A. (1979b) On the nature of the diurnal variation of sulfates at rural sites in the eastern United States. Envir. Sci. Technol. 13, $1271-1276$

Wolff G. T., Kelly N. A. and Ferman M. A. (1981) On the sources of summertime haze in the eastern United States. Science 211, 703-705.

Wolff G. T., Kelly N. A. and Ferman M. A. (1982) Source regions of summertime ozone and haze episodes in the eastern United States. Water, Air, Soil Pollut. 18, 65-81. 